\title{
New species and additional records of Leptusa from the Palaearctic region, with a focus on the faunas of China and the Caucasus region (Coleoptera: Staphylinidae: Aleocharinae)
}

\author{
With 79 figures
}

VOLKER ASSING ${ }^{1}$

${ }^{1}$ Gabelsbergerstraße 2, 30163 Hannover, Germany. - vassing.hann@t-online.de
Published on 2021-06-30
DOI: 10.21248/contrib.entomol.71.1.103-126

\begin{abstract}
Eleven species of Leptusa KrAATz, 1858 are described and illustrated: Leptusa (Aphaireleptusa) excisa spec. nov. (China: Shaanxi: Qinling Shan); L. (A.) grandipennis spec. nov. (China: Sichuan: Songpan env.); L. (A.) gonggana spec. nov. (China: Sichuan: Gongga Shan); L. (A.) habana spec. nov. (China: Yunnan: Haba Shan); L. (A.) auriculata spec. nov. (China: Yunnan: Diancang Shan); L. (Drepanoleptusa) emeiana spec. nov. (China: Sichuan: Emei Shan); L. (D.) jizuica spec. nov. (China: Yunnan: Jizu Shan); L. (D.) desculpens spec. nov. (China: Yunnan: Dawei Shan); L. (Chondrelytropisalia) procera spec. nov. (China: Sichuan: Songpan env.); L. (Yunnaleptusa) monscangi spec. nov. (China: Yunnan: Diancang Shan); L. (Chondrelytropisalia) pathibarana spec. nov. (Nepal: Taplejung district). One synonymy is proposed: Leptusa (Drepanoleptusa) emplenotoides Assing, 2006 = Leptusa (Aphaireleptusa) zhongdianensis PACE, 2010, syn. nov. Leptusa jinfomontis PACE, 2001 (previously in Nesopisalia PACE, 1992) and L. calliceroides Assing, 2004 (previously incertae sedis) are moved to the subgenus Drepanoleptusa PACE, 1982. An updated catalogue of the Leptusa species recorded from China, Taiwan, and Hong Kong is provided. The Leptusa fauna of this region now includes 73 species and three subspecies in twelve subgenera. Additional records of 22 previously named species are reported from China (eleven species), the Caucasus region (eight), Japan (two), and South Korea (one), among them several new country and regional records. Leptusa is now represented in the Palaearctic region by 418 species and 74 subspecies in 71 subgenera.
\end{abstract}

\section{Taxonomic acts}

Leptusa excisa spec. nov. - urn:lsid:zoobank.org:act:963E5B3D-F42E-411C-A6A9-F57EBCCA00E5

Leptusa grandipennis spec. nov. - urn:lsid:zoobank.org:act:476EFE09-A2F0-4227-8F55-AEC9D658E159

Leptusa gonggana spec. nov. - urn:lsid:zoobank.org:act:063A3FD3-32D8-4F48-AABA-5AB12CF1A686

Leptusa habana spec. nov. - urn:lsid:zoobank.org:act:217C5415-9901-4E13-8DD8-3F8AEA4CC8C1

Leptusa auriculata spec. nov. - urn:lsid:zoobank.org:act:1812AE30-52FF-498D-B8C2-D600DCAB2724

Leptusa emeiana spec. nov. - urn:lsid:zoobank.org:act:43EA4727-AFD3-4C04-826C-73ADCE6DAEF0

Leptusa jizuica spec. nov. - urn:lsid:zoobank.org:act:D1844B8D-2B3B-4388-933D-F2F98883B6A6

Leptusa desculpens spec. nov. - urn:lsid:zoobank.org:act:A3342BAF-F31E-43E6-9636-8250A85FBD97

Leptusa procera spec. nov. - urn:lsid:zoobank.org:act:C3881039-6537-452F-974C-48BDAFD02762

Leptusa monscangi spec. nov. - urn:lsid:zoobank.org:act:2B2ECDE0-93FD-42BB-BF27-6D7C7B8E38BC Leptusa pathibarana spec. nov. - urn:lsid:zoobank.org:act:ED968EFF-8133-4318-992C-A4D401C04ADB 


\section{Key words}

Coleoptera, Staphylinidae, Aleocharinae, Homalotini, Leptusa, taxonomy, new species, new synonymy, new subgeneric assignments, description, China, Caucasus region, new records, catalogue

\section{Zusammenfassung}

Elf Arten der Gattung Leptusa KraAtz, 1858 werden beschrieben und abgebildet: Leptusa (Aphaireleptusa) excisa spec. nov. (China: Shaanxi: Qinling Shan); L. (A.) grandipennis spec. nov. (China: Sichuan: Songpan env.); L. (A.) gonggana spec. nov. (China: Sichuan: Gongga Shan); L. (A.) habana spec. nov. (China: Yunnan: Haba Shan); L. (A.) auriculata spec. nov. (China: Yunnan: Diancang Shan); L. (Drepanoleptusa) emeiana spec. nov. (China: Sichuan: Emei Shan); L. (D.) jizuica spec. nov. (China: Yunnan: Jizu Shan); L. (D.) desculpens spec. nov. (China: Yunnan: Dawei Shan); L. (Chondrelytropisalia) procera spec. nov. (China: Sichuan: Songpan env.); L. (Yunnaleptusa) monscangi spec. nov. (China: Yunnan: Diancang Shan); L. (Chondrelytropisalia) pathibarana spec. nov. (Nepal: Taplejung district). Ein Name wird synonymisiert: Leptusa (Drepanoleptusa) emplenotoides Assing, $2006=$ Leptusa (Aphaireleptusa) zhongdianensis PACE, 2010, syn. nov. Leptusa jinfomontis PACE, 2001 (bisher in Nesopisalia PACE, 1992) und L. calliceroides Assing, 2004 (bisher incertae sedis) werden in die Untergattung Drepanoleptusa PACE, 1982 transferiert. Ein aktualisierter Katalog der Leptusa-Arten Chinas, Taiwans und Hongkongs wird erstellt. Die Leptusa-Fauna dieser Region umfasst derzeit 73 Arten und drei Unterarten in zwölf Untergattungen. Weitere Nachweise von 22 Arten, darunter mehrere Erstnachweise, werden aus China (elf Arten), der Kaukasusregion (acht), Japan (zwei) und Südkorea (eine) gemeldet. Leptusa ist derzeit in der Paläarktis mit 418 Arten und 74 Unterarten in 71 Untergattungen vertreten.

\section{Schlüsselwörter}

Coleoptera, Staphylinidae, Aleocharinae, Homalotini, Leptusa, Taxonomie, neue Arten, neue Synonymie, neue Untergattungszuordnung, Beschreibung, China, Kaukasusregion, neue Nachweise, Katalog

\section{Introduction}

The megadiverse aleocharine genus Leptusa KRAATZ, 1858 was previously represented in the Palaearctic region by a total of 408 species and 74 subspecies, with 401 species and all the subspecies assigned to 71 subgenera and nine species listed as incertae sedis (Schülke \& Smetana 2015, Assing 2017, 2019). The vast majority of the Leptusa species is micropterous, more or less locally endemic, and confined to montane, subalpine, and alpine habitats. Diversity hotspots are the mountain ranges of the northern Iberian Peninsula, Italy, and the Balkans, the Alps, the Caucasus region (including Northeast Turkey and North Iran), the Himalayan region, and the mountain ranges of China and Taiwan (PACe 1989, Assing 2002, 2011a).

Assing $(2017,2019)$ summarised the fauna of the Caucasus region. According to a catalogue provided by Assing (2010), the Leptusa fauna of China and Taiwan was composed of 65 named species and subspecies in twelve subgenera. Two species were added by PACE (2010).

The present study is based on Leptusa material made available to me from various sources, primarily by Aleš Smetana (Ottawa) and Michael Schülke (Berlin). An examination of this material revealed that it included as many as eleven unnamed species, ten of them from China, plus numerous records of previously described species.

\section{Material and methods}

The material examined in the course of the present study is deposited in the following public and private collections:

\section{CAS Chinese Academy of Sciences, Beijing \\ CNC Canadian National Collection of Insects, Arach- nids and Nematodes (A. Brunke, A. Smetana) \\ HNHM Hungarian Natural History Museum (Gy. Makranczy)}

MNB Museum für Naturkunde, Berlin (coll. Schülke)

NIBR National Institute of Biological Resources, Incheon, Korea

NME Naturkundemuseum Erfurt (M. Hartmann)

cAss author's private collection

cGon private collection Andrey Gontarenko, Odessa

cKov private collection Alexey Kovalev, St. Petersburg

The morphological studies were conducted using Stemi SV 11 (Zeiss) and Discovery V12 (Zeiss) microscopes, and a Jenalab compound microscope (Carl Zeiss Jena). The images were created using digital cameras (Axiocam ERc 5s, Nikon Coolpix 995), as well as Labscope and Picolay software.

Body length was measured from the anterior margin of the labrum to the apex of the abdomen, the length of the forebody from the anterior margin of the labrum to the posterior margin of the elytra, head length from the ante- 
rior margin of the clypeus to the posterior constriction of the head, elytral length at the suture from the apex of the scutellum to the posterior margin of the elytra, and the length of the aedeagus from the apex of the ventral process to the base of the aedeagal capsule. The "parameral" side (i.e., the side where the sperm duct enters) is referred to as the ventral, the opposite side as the dorsal aspect.

\section{Results}

An examination of many hundred specimens primarily from China and from the Caucasus regions yielded eleven new species and numerous records of previously named species, among them several new country and regional records. Moreover, a new synonymy and two new subgeneric assignments are proposed.

\section{The Leptusa fauna of China}

Including ten newly described species and a new synonymy, the Leptusa fauna of China, Taiwan, and Hong Kong now includes 73 species and three subspecies in twelve subgenera, with three species not assigned to any of the available subgenera. In view of the number of new species and of the fact that some species have not yet been revised, it appears likely that additional species and synonymies remain to be discovered in the future.

The distributions of two of the newly described species are somewhat doubtful. One of them, L. auriculata, was collected in several localities in Diangcang Shan and one in Emei Shan, and the other, L. emeiana, was found in several localities in Emei Shan and one in Diancang Shan. The respective specimens were collected by the same entomologist in mountain ranges separated by a considerable distance in the same year, suggesting that these records may be partly based on mislabeled material.

\section{Updated catalogue of the Leptusa species of China, Taiwan, and Hong Kong}

The subgenera and the species within each subgenus are arranged alphabetically. The references are sorted by publication year.

The literature references are abbreviated as follows: A02 = Assing (2002); A04 = Assing (2004); A06 = Assing (2006); A08 = Assing (2008); A10 = Assing (2010); App = Assing (present paper); P92 = PACE (1992); P95 = PACE (1995); P96 = PACE (1996); P97 = PACE (1997); P99 = PACE (1999); P01 = PACE (2001); P04 = PACE (2004); P07 = PACE (2007); P10 = PACE (2010).

The subgeneric assignments, specific identities, and status of L. qinlingensis (Akratopisalia), L. erlangensis (Drepanoleptusa), L. microvolans (Drepanoleptusa), L. rorata (Drepanoleptusa), L. taichungensis (Homopisalia), and L. kaohsiungensis (Kochliodepisalia) are doubtful, since the male sexual characters are unknown. In the catalogue, these species are marked with an asterisk.

\begin{tabular}{|c|c|c|}
\hline Subgenus/Species & Distribution & References \\
\hline \multicolumn{3}{|l|}{ Akratopisalia PACE, 1996} \\
\hline cribrata PACE, 1996 & Taiwan & P96, A02 \\
\hline kangdingensis PACE, 2010 & Sichuan: Daxue Shan & P10 \\
\hline limata Assing, 2002 & China: Shaanxi, Hubei, Beijing & A02, A04, App \\
\hline${ }^{*}$ qinlingensis PACE, 1999 & China: Shaanxi: Qinling Shan & P99 \\
\hline xianensis PACE, 1999 & China: Shaanxi, Gansu & P99, App \\
\hline \multicolumn{3}{|l|}{ Anosiopisalia PACE, 1995} \\
\hline nemoricultrix PACE 1995 & Taiwan & P95 \\
\hline \multicolumn{3}{|l|}{$\begin{array}{l}\text { Aphaireleptusa PACE, } 1996 \\
=\text { Aleteleptusa PACE, } 1997 \\
=\text { Mimumenepisalia PACE, } 1997\end{array}$} \\
\hline acuta Assing, 2002 & Taiwan & A02, P07 \\
\hline anmashanensis PACE, 1996 & Taiwan & P96, A02, P07 \\
\hline auriculata spec. nov. & China: Yunnan: Diancang Shan & App \\
\hline chinensis PACE, 1997 & China: Sichuan, Shaanxi, Yunnan & P97, A02, P04, A06, App \\
\hline excisa spec. nov. & China: Shaanxi: Qinling Shan & App \\
\hline formidabilis PACE, 1996 & Taiwan & P96, A02 \\
\hline gansuensis PACE, 1997 & China: Gansu, Sichuan & P97, P10, App \\
\hline
\end{tabular}




\begin{tabular}{|c|c|c|}
\hline Subgenus/Species & Distribution & References \\
\hline ganzica Assing, 2002 & China: Sichuan: Daxue Shan & A02 \\
\hline $\begin{array}{l}\text { gonggamontis PACE, } 1997 \\
=\text { daxuemontis PACE, } 2001\end{array}$ & $\begin{array}{l}\text { China: Sichuan: Gongga Shan, Erlang } \\
\text { Shan }\end{array}$ & P97, P01, A02, App \\
\hline gonggana spec. nov. & China: Sichuan: Gongga Shan & App \\
\hline grandipennis spec. nov. & China: Sichuan: Songpan env. & App \\
\hline habana spec. nov. & China: Yunnan: Haba Shan & App \\
\hline jiudingensis PACE, 1999 & China: Sichuan & P99 \\
\hline michai Assing, 2002 & China: Shaanxi: Qinling Shan & $\mathrm{A} 02$ \\
\hline semivolans PACE, 1996 & Taiwan & P96, A02 \\
\hline tenchiensis PACE, 1996 & Taiwan & P96, A02, P07 \\
\hline tenuicornis Assing, 2006 & China: Yunnan: Zhongdian env. & A06 \\
\hline turgida Assing, 2006 & China: Yunnan: Zhongdian env. & A06 \\
\hline wolongensis Assing, 2002 & China: Sichuan: Qionglai Shan & A02 \\
\hline xiahensis PACE, 1997 & China: Gansu, Sichuan & P97, P04 \\
\hline xuemontis PACE, 2001 & China: Yunnan: Xue Shan & $\mathrm{P} 01, \mathrm{~A} 04, \mathrm{~A} 06, \mathrm{P} 10$ \\
\hline yunnanensis PACE, 2001 & China: Yunnan & P01, A06 \\
\hline \multicolumn{3}{|l|}{ Chondrelytropisalia SCHEERPELTZ, 1976} \\
\hline procera spec. nov. & China: Sichuan: Songpan env. & App \\
\hline proiecta Assing, 2008 & China: Yunnan: Gaoligong Shan & A08, A10 \\
\hline quinqueimpressa Assing, 2008 & China: Yunnan: Gaoligong Shan & $\mathrm{A} 08, \mathrm{~A} 10$ \\
\hline tectusoides Assing, 2002 & China: Sichuan: Daxiang Ling & $\mathrm{A} 02, \mathrm{~A} 08$ \\
\hline \multicolumn{3}{|l|}{ Drepanoleptusa PACE, 1982} \\
\hline calliceroides Assing, 2004 & China: Yunnan: Zhongdian env. & A04, App \\
\hline chengduensis PACE, 2001 & China: Sichuan, Shaanxi & $\mathrm{P} 01, \mathrm{~A} 02, \mathrm{~A} 04$ \\
\hline desculpens spec. nov. & China: Yunnan: Dawei Shan & App \\
\hline discolor Assing, 2006 & China: Yunnan & A06, A08 \\
\hline emeiana spec. nov. & China: Sichuan: Emei Shan & App \\
\hline $\begin{array}{l}\text { emplenotoides AssiNG, } 2006 \\
\text { = zhongdianensis PACE, 2010; syn. nov. }\end{array}$ & China: Yunnan, Sichuan & A06, P10, App \\
\hline${ }^{*}$ erlangensis PACE, 1999 & China: Sichuan: Erlang Shan & P99 \\
\hline jinfomontis PACE, 2001 & China: Sichuan: Jinfo Shan & P01, App \\
\hline jizuica spec. nov. & China: Yunnan: Jizu Shan & App \\
\hline${ }^{*}$ microvolans PACE, 1997 & Hong Kong & P97 \\
\hline pollicita AssING, 2010 & China: Yunnan & A10, App \\
\hline puetzi Assing, 2008 & China: Yunnan: Gaoligong Shan & A08 \\
\hline${ }^{*}$ rorata PACE, 1995 & Taiwan & P95 \\
\hline rougemonti PACE, 1997 & China: Shanxi, Gansu & P97, App \\
\hline sichuanensis PACE, 1997 & China: Sichuan, Yunnan & P97, P04 \\
\hline stimulans Assing, 2008 & China: Yunnan: Gaoligong Shan & A08 \\
\hline taiwanensis PACE, 1992 & Taiwan & P92, P07 \\
\hline titillans Assing, 2002 & China: Sichuan: Daxue Shan & $\mathrm{A} 02, \mathrm{~A} 08$ \\
\hline wuyica Assing, 2002 & China: Fujian: Wuyi Shan & A02 \\
\hline \multicolumn{3}{|l|}{ Dysleptusa PACE, 1982} \\
\hline sinorum PACE, 2001 & China: Shaanxi: Qinling Shan & P01, App \\
\hline
\end{tabular}




\begin{tabular}{|c|c|c|}
\hline Subgenus/Species & Distribution & References \\
\hline \multicolumn{3}{|l|}{ Eospisalia PACE, 1982} \\
\hline pingtungensis PACE, 1995 & Taiwan & P95 \\
\hline \multicolumn{3}{|l|}{ Heteroleptusa PACE, 1989} \\
\hline flagellata Assing, 2002 & China: Shaanxi: Qinling Shan & A02, App \\
\hline hastata Assing, 2002 & China: Shaanxi: Daba Shan & $\mathrm{A} 02$ \\
\hline peinantamontis PACE, 2007 & Taiwan & P07 \\
\hline peregrina PACE, 1995 & Taiwan & $\mathrm{P} 95, \mathrm{~A} 02, \mathrm{P} 07$ \\
\hline shaanxiensis PACE, 1999 & China: Shaanxi, Sichuan & P99, P10 \\
\hline \multicolumn{3}{|l|}{ Homopisalia PACE, 1982} \\
\hline${ }^{*}$ taichungensis PACE, 1996 & Taiwan & P96 \\
\hline \multicolumn{3}{|l|}{ Kochliodepisalia PACE, 1996} \\
\hline${ }^{*}$ kaohsiungensis PACE, 2007 & Taiwan & $\mathrm{P} 07$ \\
\hline spirarum PACE, 1996 & Taiwan & P96, A02 \\
\hline \multicolumn{3}{|l|}{ Nesopisalia PACE, 1992} \\
\hline centralis centralis PACE, 1992 & Taiwan & P92 \\
\hline centralis reposita PACE, 1992 & Taiwan & P92 \\
\hline centralis tarokensis PACE, 1992 & Taiwan & P92 \\
\hline centralis yushanensis PACE, 1992 & Taiwan & P92, P07 \\
\hline \multicolumn{3}{|l|}{ Yunnaleptusa Assing, 2008} \\
\hline armatissima Assing, 2008 & China: Yunnan: Diancang Shan & A08, A10, App \\
\hline cultellata Assing, 2008 & China: Yunnan: Gaoligong Shan & A08, A10 \\
\hline curvata Assing, 2006 & China: Yunnan: Zhongdian env. & A06, A08 \\
\hline hamulata Assing, 2010 & China: Yunnan: Gaoligong Shan & A10 \\
\hline monscangi spec. nov. & China: Yunnan: Diancang Shan & App \\
\hline parvibulbata Assing, 2008 & China: Yunnan: Gaoligong Shan & A08, A10 \\
\hline recta Assing, 2006 & China: Yunnan: Gaoligong Shan & A06, A08, App \\
\hline zhemomontis Assing, 2010 & China: Yunnan: Zhemo Shan & $\mathrm{A} 10$ \\
\hline \multicolumn{3}{|l|}{ incertae sedis } \\
\hline excaecata Assing, 2002 & China: Shaanxi: Daba Shan & $\mathrm{A} 02$ \\
\hline marmotae Assing, 2002 & China: Sichuan: Shalui Shan & $\mathrm{A} 02$ \\
\hline schuelkei PACE, 1999 & China: Shaanxi & P99, A08 \\
\hline
\end{tabular}

\section{Leptusa (Dysleptusa) sinorum PACE, 2001}

Material examined: China: $10^{\star}$, S-Shaanxi, SW Zhouzhi, Qinling Shan, $33^{\circ} 44^{\prime} \mathrm{N}, 107^{\circ} 58^{\prime} \mathrm{E}, 1900 \mathrm{~m}$, NE-slope, stream valley, mixed forest, litter and soil sifted, 25.VII.2012, leg. Schülke (cAss).

This species was previously known only from the type locality, which is situated close to the above locality.

\section{Leptusa (Akratopisalia) xianensis PACE, 1999}

Material examined: China: 6 exs., Gansu, Dagcanglhamo (= Langmusi) env., $34^{\circ} 04^{\prime} \mathrm{N}, 102^{\circ} 37^{\prime} \mathrm{E}, 3460-3640 \mathrm{~m}$, wet coniferous forest with rhododendron, detritus and wet moss sifted, 25.VI.2005, leg. Hájek, Král \& Růžička (MNB, cAss).

The original description is based on nine type specimens from Qinling Shan in Shaanxi (PACE 1999). The species was subsequently reported from a second locality in Qinling Shan, Shaanxi (Assing 2002). The above specimens represent the first record from Gansu.

\section{Leptusa (Akratopisalia) limata Assing, 2002}

Material examined: China: 4 exs., Shaanxi, Qinling Shan, pass on road Zhouzhi-Foping, $105 \mathrm{~km}$ SW Xi'an, 
$33^{\circ} 44^{\prime} \mathrm{N}, 107^{\circ} 59^{\prime \prime} \mathrm{E}, 1990 \mathrm{~m}$, small stream valley with mixed deciduous forest and bamboo undergrowth, sifted, 2-4.VII.2001, leg. Schülke (MNB, cAss); 2 exs., S-Shaanxi Micang Shan, $40 \mathrm{~km}$ SW Hanzhong, $32^{\circ} 52^{\prime} \mathrm{N}, 106^{\circ} 37^{\prime} \mathrm{E}$, $1530 \mathrm{~m}, \mathrm{~N}$-slope, mixed secondary forest, litter and moss sifted, 16.VIII.2012, leg. Schülke (MNB, cAss); 2 exs., Hubei, Daba Shan, mountain range NE Muyuping, pass $12 \mathrm{~km} \mathrm{~N}$ Muyuping, $31^{\circ} 32^{\prime} \mathrm{N}, 110^{\circ} 26^{\prime} \mathrm{E}, 2380 \mathrm{~m}$, young mixed deciduous forest, sifted, 17.VII.2001, leg. Schülke (MNB, cAss).

This widespread species has been recorded from Shaanxi, Hubei, and Beijing (Assing 2002, 2004).

\section{Leptusa (Aphaireleptusa) gansuensis PACE, 1997}

Material examined: China: Sichuan: 2 exs., Ganzi Tibetian Autonomous Pref., Daxue Shan, Mugecuo, $15 \mathrm{~km}$ NW Kangding, upper lake, $30^{\circ} 09^{\prime} \mathrm{N}, 101^{\circ} 51^{\prime} \mathrm{E}, 3700 \mathrm{~m}$, 27.VI.1999, leg. Pütz (cPüt); 4 exs., Sichuan, Ganzi Tibetian Autonomous Pref., Yajiang Co., Shalui Shan, 32 km WNW Yajiang, $30^{\circ} 08^{\prime} \mathrm{N}, 100^{\circ} 43^{\prime} \mathrm{E}, 4300 \mathrm{~m}, 2$.VII.1999, leg. Pütz, Schülke (MNB, cPüt, cAss); 2 exs., $23 \mathrm{~km} \mathrm{E}$ Songpan, $32^{\circ} 38^{\prime} \mathrm{N}, 103^{\circ} 51^{\prime} \mathrm{E}, 3920 \mathrm{~m}$, sifted, 25.V.2012, leg. Grebennikov (CNC, cAss); 3 exs., 23 km E Songpan, $32^{\circ} 38^{\prime} \mathrm{N}, 103^{\circ} 49^{\prime} \mathrm{E}, 3840 \mathrm{~m}, 27 . \mathrm{V} .2012$, leg. Grebennikov (CNC, cAss); 2 exs., $23 \mathrm{~km}$ E Songpan, $32^{\circ} 38^{\prime} \mathrm{N}$, $103^{\circ} 49^{\prime} \mathrm{E}, 3930 \mathrm{~m}$, sifted, 28.V.2012, leg. Grebennikov (CNC, cAss); 1 ex., 23 km E Songpan, 32 $38^{\prime} \mathrm{N}, 103^{\circ} 50^{\prime} \mathrm{E}$, $3860 \mathrm{~m}$, sifted, 26.V.2012, leg. Grebennikov (CNC); 1 ex., $23 \mathrm{~km}$ E Songpan, $32^{\circ} 38^{\prime} \mathrm{N}, 103^{\circ} 49^{\prime} \mathrm{E}, 3760 \mathrm{~m}$, sifted, 27.V.2012, leg. Grebennikov (CNC).

Leptusa gansuensis was originally described based on nine specimens from the environs in Xiahe, Gansu, and subsequently reported also from Shalui Shan in Ganzi Tibetian Autonomous Prefecture (PACE 1997, 2010).

\section{Leptusa (Aphaireleptusa) chinensis PACE, 1997}

Material examined: China: Sichuan: 33 exs., Emei Shan, $29^{\circ} 31^{\prime} \mathrm{N}, 103^{\circ} 20^{\prime} \mathrm{E}, 3035 \mathrm{~m}$, sifted, 14.VI.2010, leg. Grebennikov (CNC, cAss); 21 exs., Emei Shan, 29³2'N, $103^{\circ} 20^{\prime} \mathrm{m}, 2930 \mathrm{~m}$, sifted, 15.VI.2010, leg. Grebennikov (CNC, cAss); 6 exs., Emei Shan, $29^{\circ} 33^{\prime} \mathrm{N} ; 103^{\circ} 20^{\prime} \mathrm{E}$, $2310 \mathrm{~m}$, sifted, 20.VI.2010, leg. Grebennikov (CNC, cAss); 2 exs., Emei Shan, $29^{\circ} 34^{\prime} \mathrm{N}, 103^{\circ} 21^{\prime} \mathrm{E}, 1800-$ $2400 \mathrm{~m}$, sifted, 27.VI.-5.VII.2009, leg. Grebennikov (CNC, (cAss); 1 ex., Emei Shan, 293' N, 103²0'E, 2440 m, sifted, 18.VI.2010, leg. Grebennikov (CNC); 2 exs., Emei Shan, 29 $32^{\prime} \mathrm{N}, 103^{\circ} 20^{\prime} \mathrm{E}, 2930 \mathrm{~m}$, sifted, 15.VI.2010, leg. Grebennikov (CNC, cAss); 18 exs., Gongga Shan, NE-slope, $29^{\circ} 56^{\prime} \mathrm{N}, 101^{\circ} 59^{\prime} \mathrm{E}, 3550 \mathrm{~m}$, sifted, 17.VI.2011, leg. Grebennikov (CNC, cAss); 7 exs., same data, but 3660 m (CNC, cAss); 1 ex., Daxue Shan, Kangding env., Paoma Shan, $30^{\circ} 03^{\prime} \mathrm{N}, 101^{\circ} 58^{\prime} \mathrm{E}$,
2700-2900 m, 22.V.1997, leg. Schülke (MNB); 1 ex., Ganzi Tibet. Aut. Pref., Daxue Shan, Kangding Co., Mu Ge Cou, $2 \mathrm{~km}$ abover lower lake, $30^{\circ} 11^{\prime} \mathrm{N}, 101^{\circ} 52^{\prime} \mathrm{E}$, 5.VII.1999, leg. Schülke (cAss). Yunnan: 5 exs., Dali env., Cang Shan, E-slope, $25^{\circ} 40^{\prime} \mathrm{N}, 100^{\circ} 08^{\prime} \mathrm{E}, 2730 \mathrm{~m}$, 13.V.2010, leg. Grebennikov (CNC, cAss).

This is the most common and most widespread representative of the subgenus Aphaireleptusa in mainland China. It has been recorded from numerous localities in Sichuan and Yunnan, but was previously unknown from Emei Shan and Cang (Diancang) Shan (Assing 2002, 2006, PACE 1997, 2004).

\section{Leptusa (Aphaireleptusa) excisa spec. nov. urn:Isid:zoobank.org:act:963E5B3D-F42E-411C-A6A9-F57EBCCA00E5 (Figs 1, 12, 19-25)}

Type material: Holotype o*: "P.R. CHINA, Shaanxi, S slope Qin Ling Shan, N33 ${ }^{\circ} 51^{\prime} 40^{\prime \prime}$ E108 ${ }^{\circ} 9^{\prime} 27^{\prime \prime}, 15 . v .2011$, 2000-2600 m, sift01, V. Grebennikov / Holotypus o Leptusa excisa sp. n. det. V. Assing 2020" (CAS). Paratypes: 22 exs.: same data as holotype (CNC, cAss); 4 exs.: "P.R. CHINA, Shaanxi, S slope Qin Ling Shan, N3401'07" E10751'50", 17.v.2011, 1700-2200 m, sift02, V. Grebennikov" (CNC).

Etymology: The specific epithet (adjective) alludes to the distinctly concave posterior margin of the male tergite VIII.

Description: Body length 2.4-3.2 mm; length of forebody 1.2-1.5 mm. Habitus as in Fig. 1. Colouration: head and pronotum blackish-brown to black; elytra reddish to dark-red; abdomen reddish to reddish-brown with tergite VI and the anterior half of tergite VII blackish; legs reddish; antennae reddish to reddish-brown with the basal 3-4 antennomeres yellowish-red.

Head (Fig. 12) transverse; punctation rather coarse, very dense, and somewhat umbilicate; interstices reduced to narrow ridges, without microsculpture. Eyes approximately as long as postocular region in lateral view. Antennae slender, gradually and moderately incrassate apically, preapical antennomeres approximately 1.5 times as broad as long.

Pronotum (Fig. 12) 1.25-1.30 times as broad as long and approximately 1.25 times as broad as head; maximal width in anterior half; posterior angles angularly marked; punctation coarse, very dense, and distinctly granulose; interstices without microsculpture.

Elytra (Fig. 12) approximately as long as pronotum; punctation coarse, very dense, and defined. Hind wings present.

Abdomen narrower than elytra; punctation fine and rather dense, very coarse and very dense in anterior impressions of tergites III-VI; interstices without microsculpture and glossy; posterior margin of tergite VII with palisade fringe. 




1

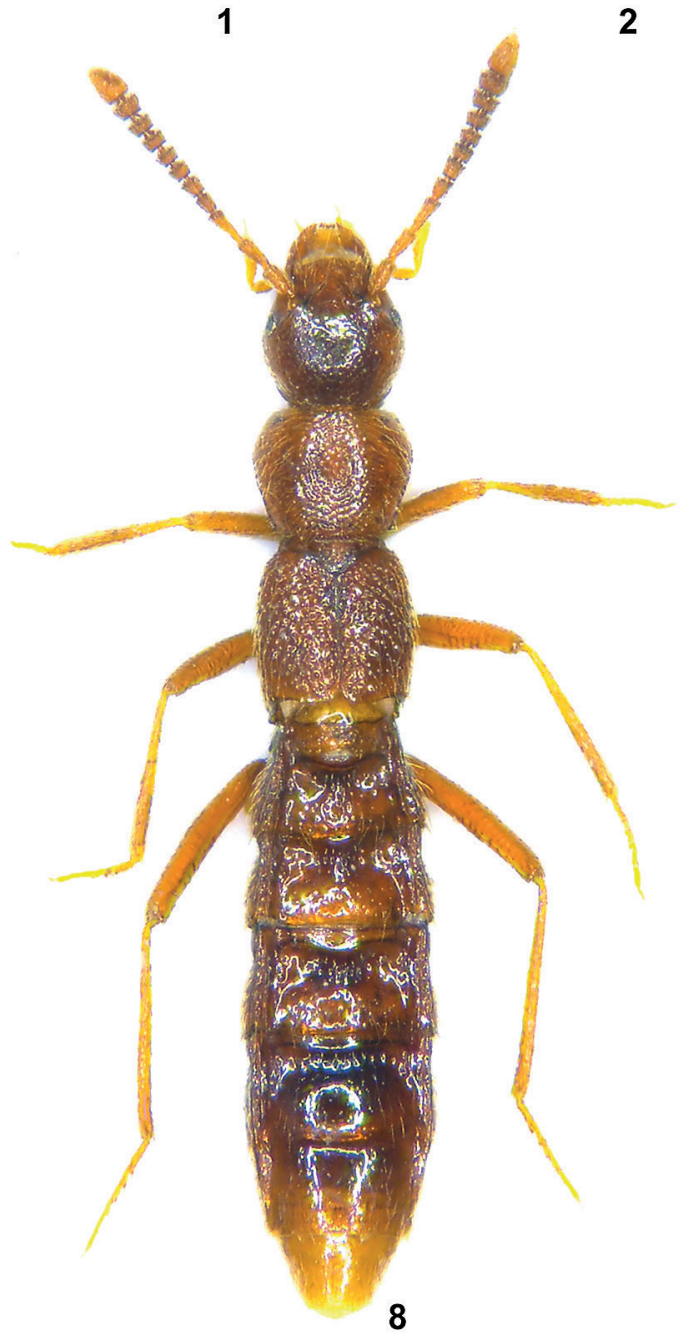

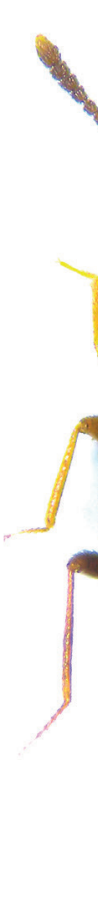
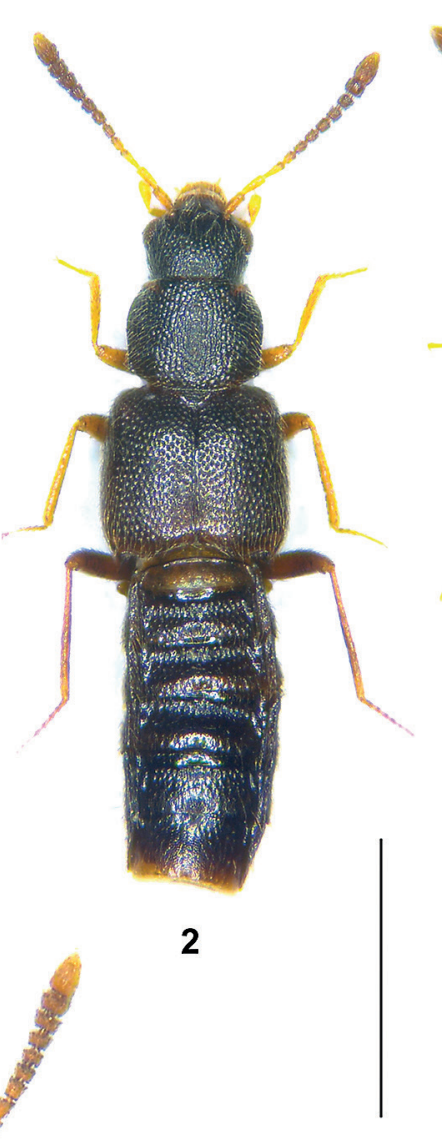

2

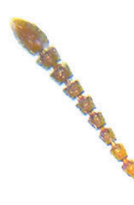



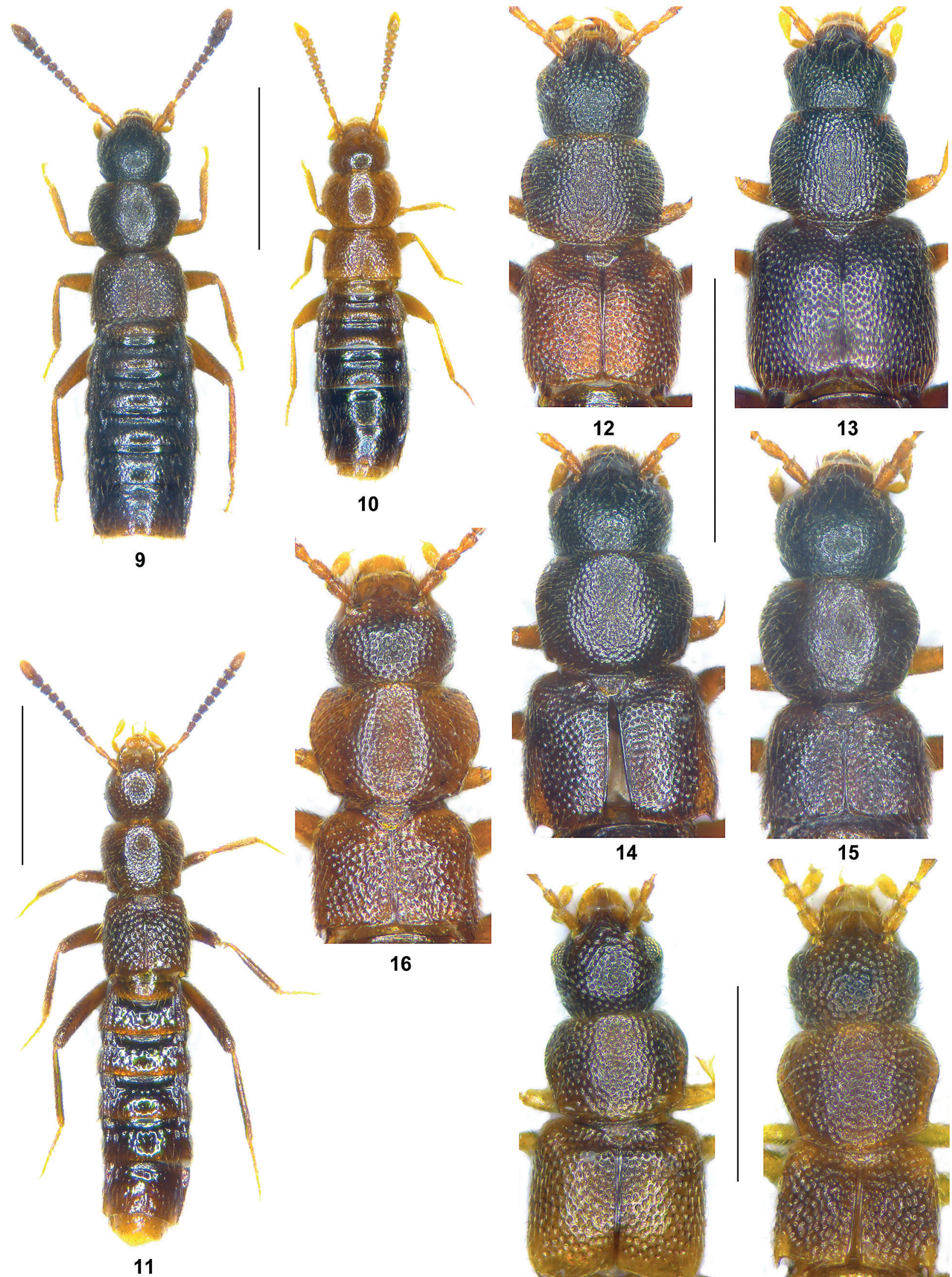

16
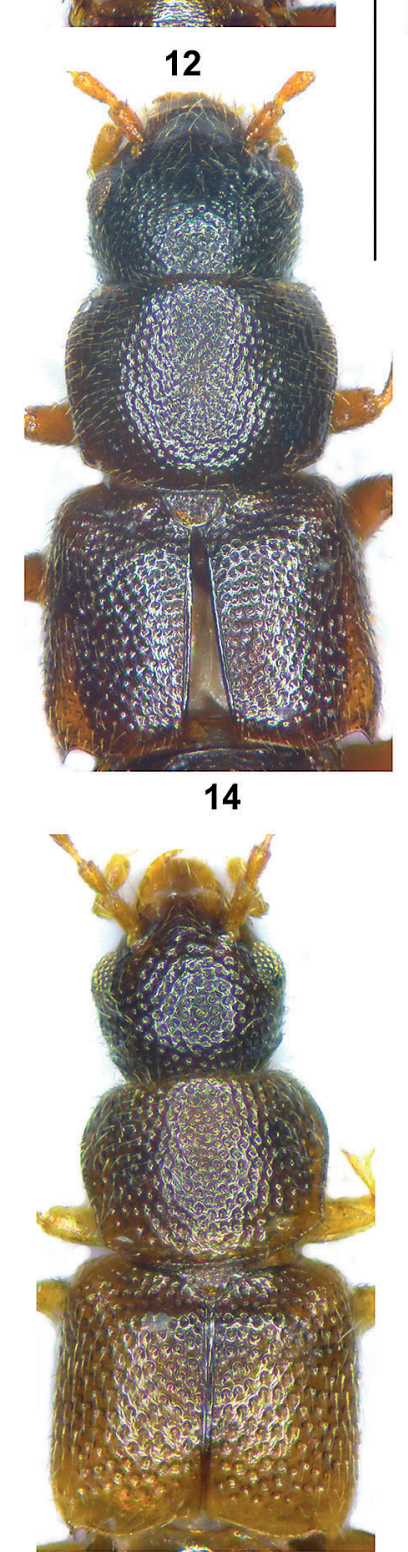

17
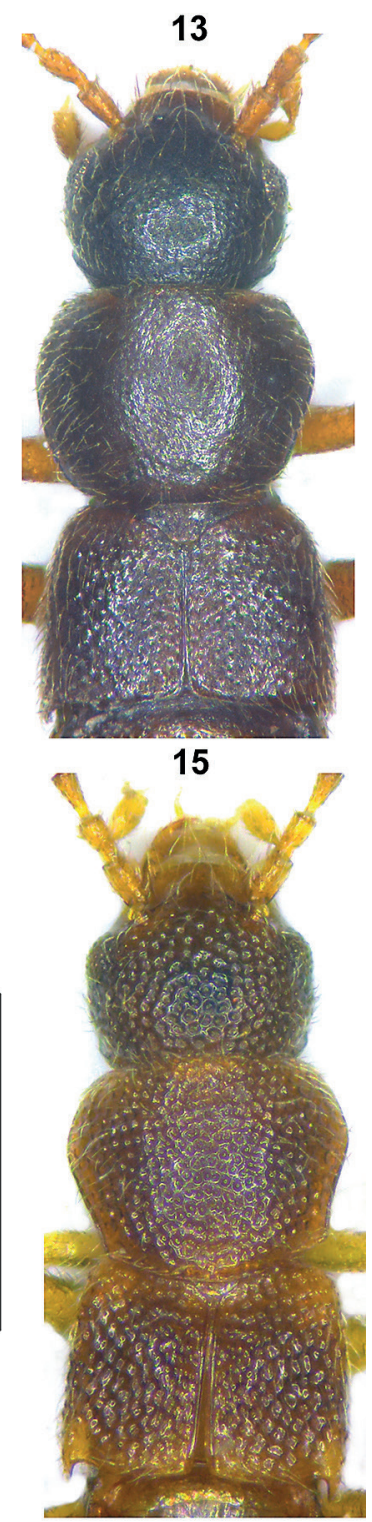

18

Figs 9-18: Male habitus (9-11) and forebody (12-18) of Leptusa spp. 9, 15 - L. habana; 10 - L. monscangi; 11 - L. pathibarana; 12 - L. excisa; 13 - L. grandipennis; 14 - L. gonggana; 16 - L. auriculata; 17 - L. jizuica; 18 - L. desculpens. Scale bars: 9-16: 1.0 mm; 17-18: $0.5 \mathrm{~mm}$. 


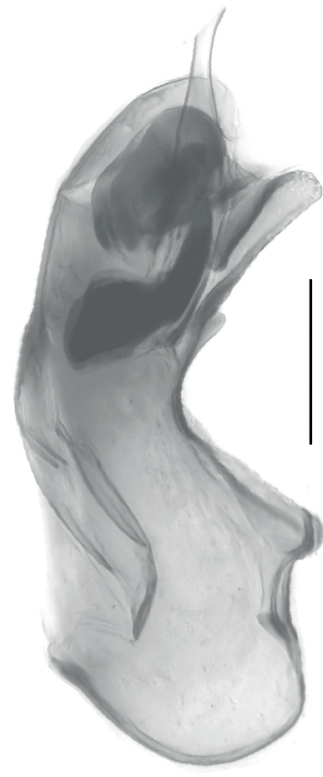

19



21

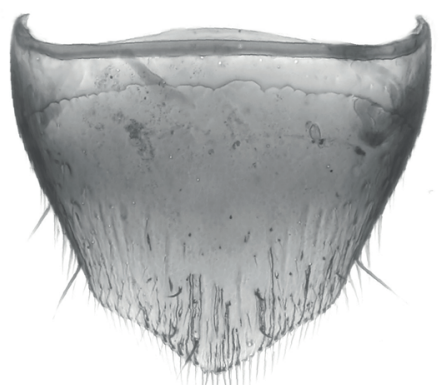

23



30

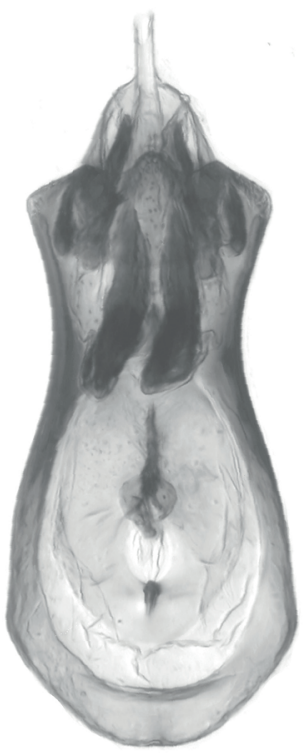

20

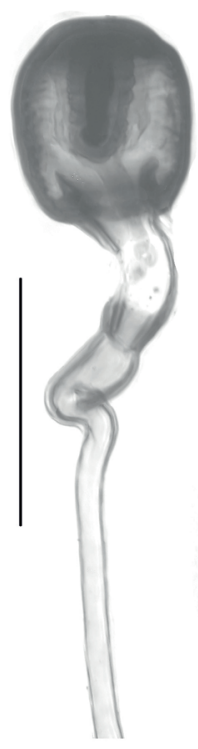

25



24

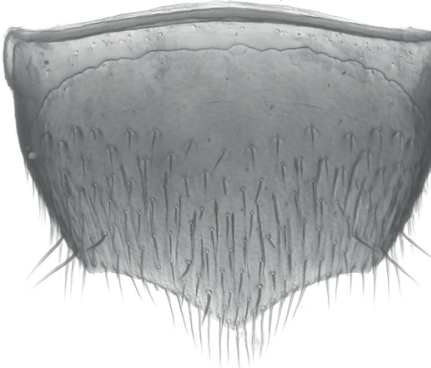

29

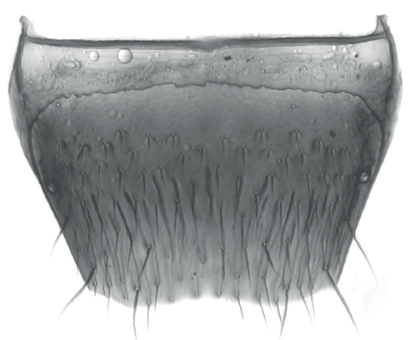

28

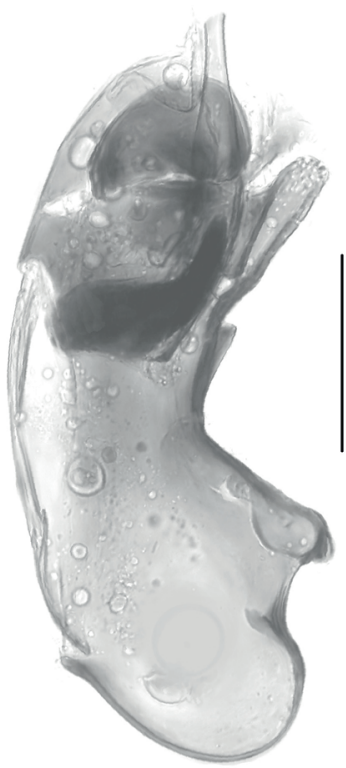

26

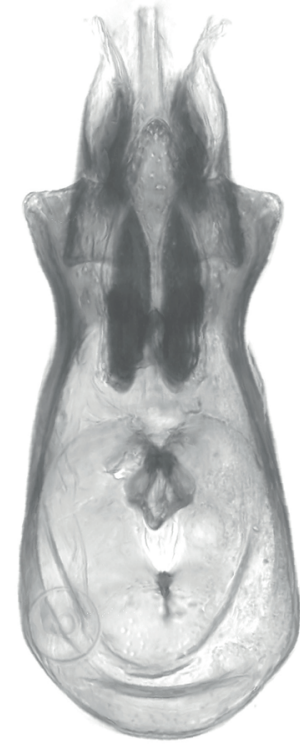

27

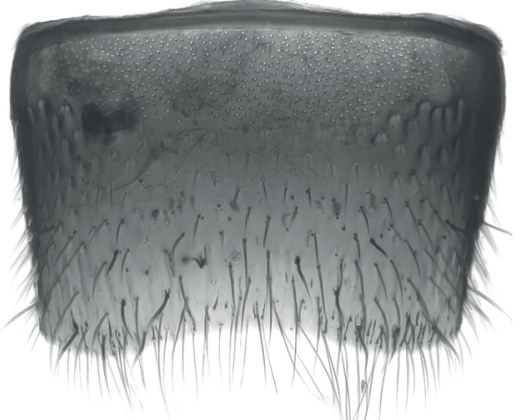

22

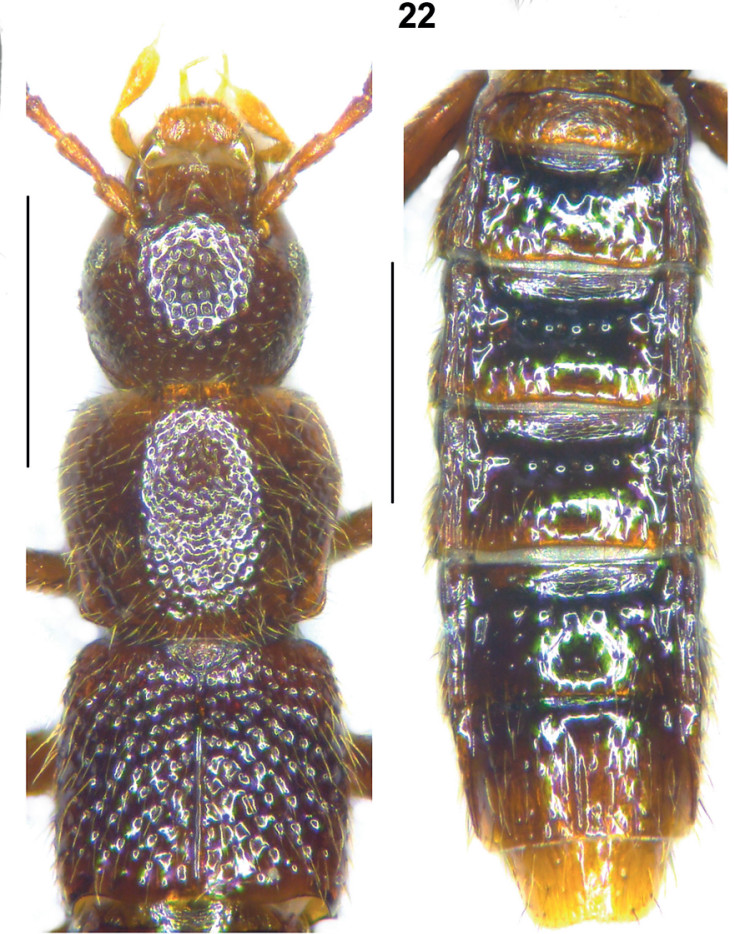

31

Figs 19-32: Leptusa excisa (19-25), L. grandipennis (26-29), L. gonggana (30), and L. pathibarana (31-32). 19-20, 26-27 - median lobe of aedeagus in lateral and in ventral view; 21, 28 -male tergite VIII; 22 - male sternite VII; 23, 29-30 - male sternite VIII; 24 - female sternite VIII; 25 - spermatheca; 31 - forebody; 32 - male abdomen. Scale bars: 31-32: 0.5 mm; 21-24, 28-30: 0.2 mm; 19-20, 25-27: $0.1 \mathrm{~mm}$. 


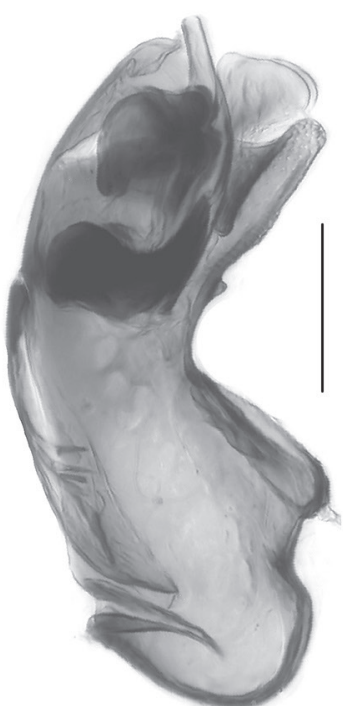

33

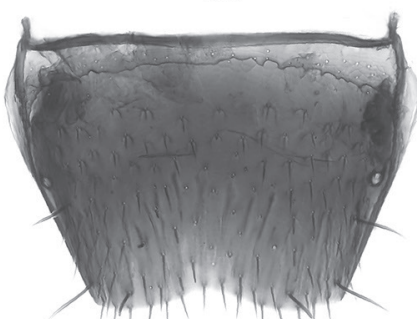

35
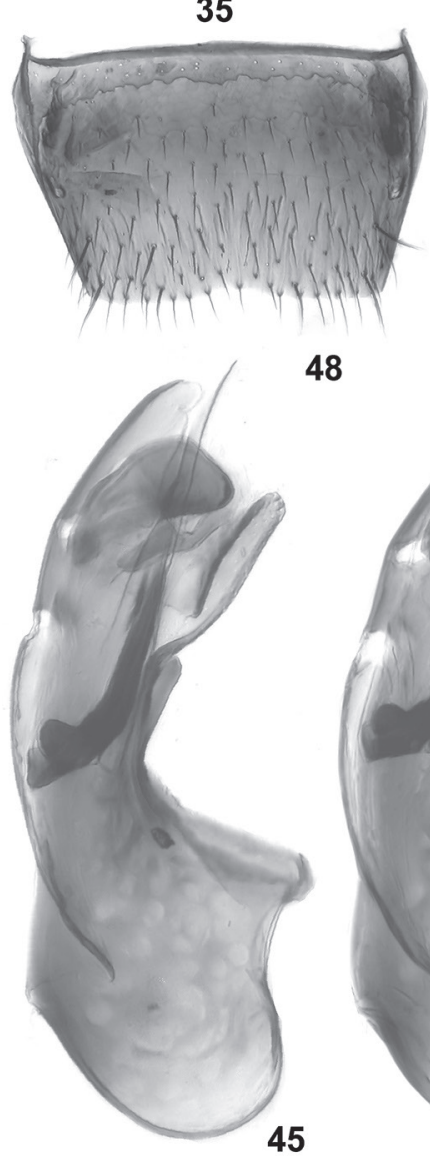

48



34

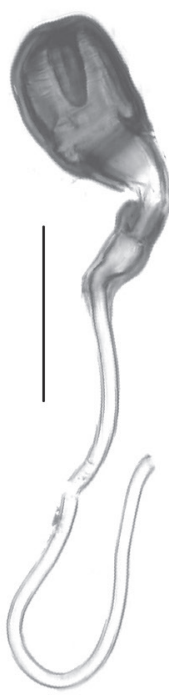

38

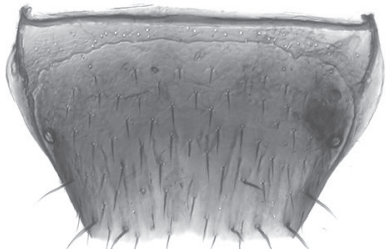

36

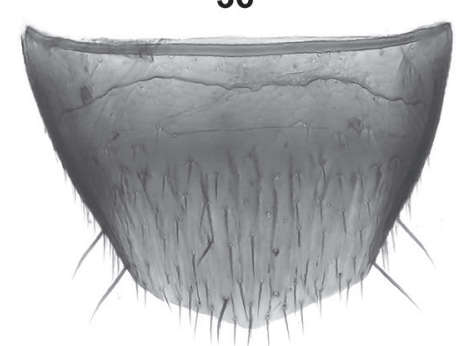

37

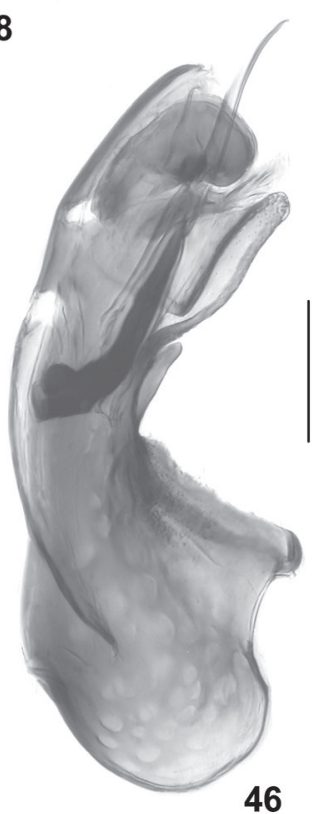

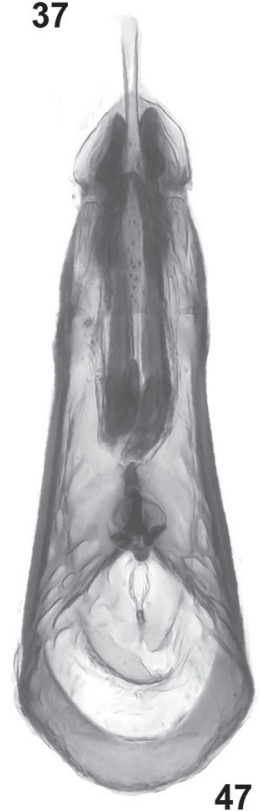

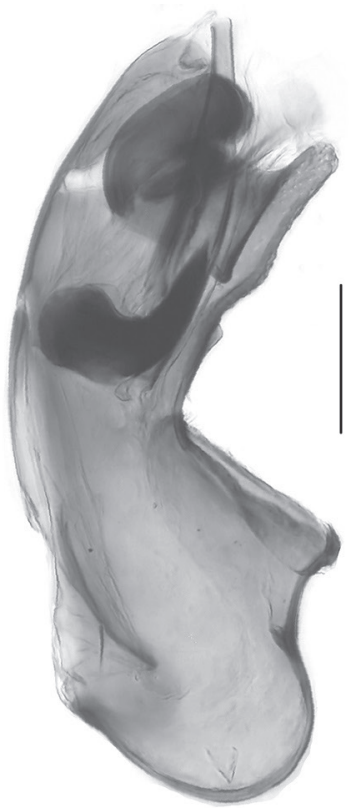

39

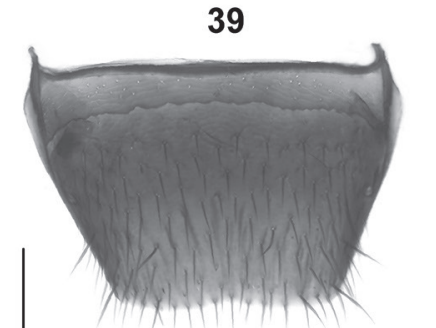

41


50



40


44

Figs 33-50: Leptusa gonggana (33-38), L. habana (39-44), and L. auriculata (45-50). 33-34, 39-40, 45-47 - median lobe of aedeagus in lateral and in ventral view; 35, 41, 48 - male tergite VIII; 36, 49 - female tergite VIII; 37, 43 - female sternite VIII; 38, 44, 50 - spermatheca; 42 - male sternite VIII. Scale bars: 35-37, 41-43, 48-49: 0.2 mm; 33-34, 38-40, 44-47, 50: 0.1 mm. 


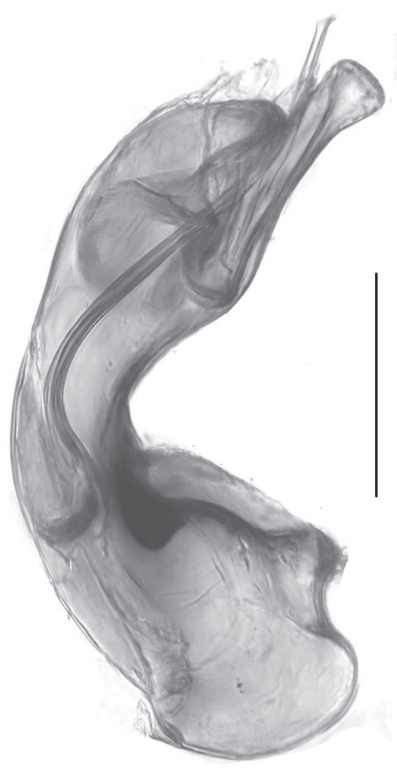

51

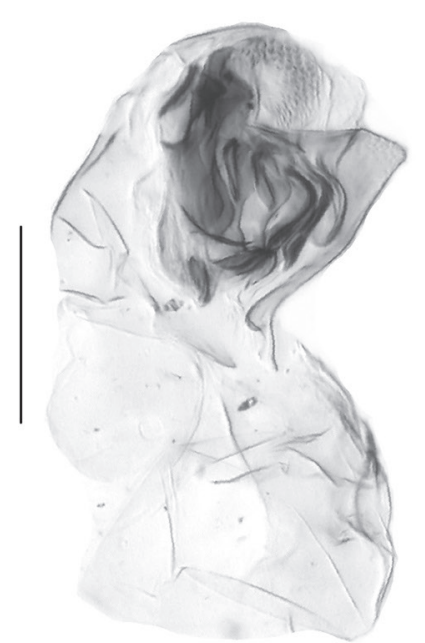

58

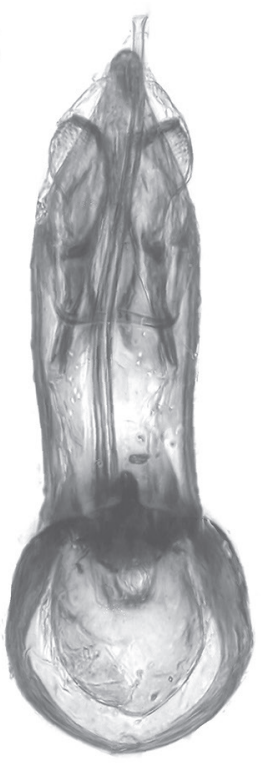

52



53

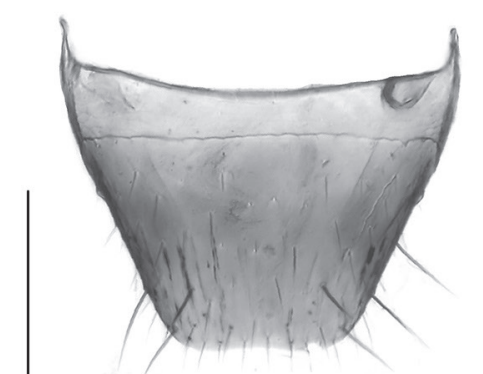

59



60

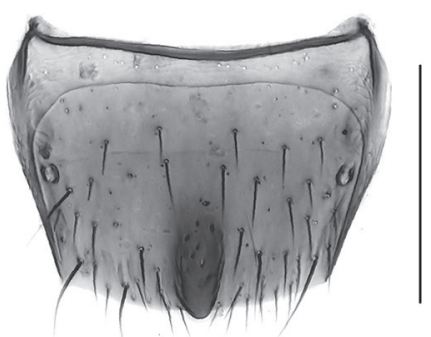

63

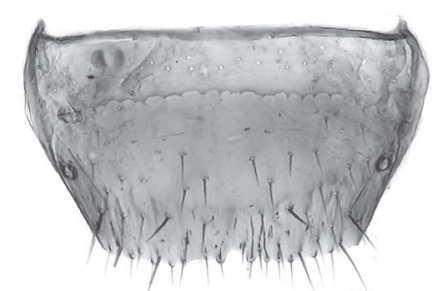

54



55



56

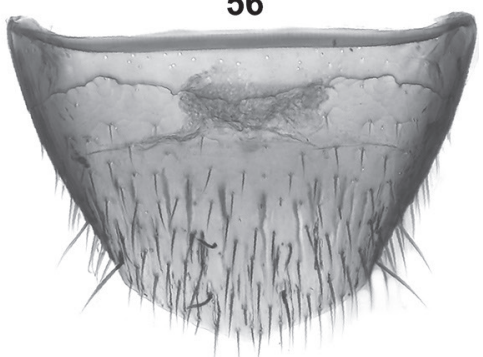

57

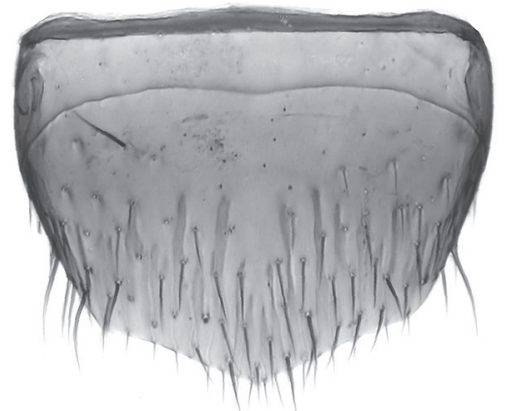

64

Figs 51-64: Leptusa emeiana (51-55), L. auriculata (56-57), L. jizuica (58-60), and L. desculpens (61-64). 51-52, 58, 61-62 - median lobe of aedeagus in lateral and in ventral view; 53 - paramere; 54, 59, 63 - male tergite VIII; 55-56, 60, 64 - male sternite VIII; 57 - female sternite VIII. Scale bars: 54-57, 59-60, 63-64: 0.2 mm; 51-53, 58, 61-62: $0.1 \mathrm{~mm}$. 


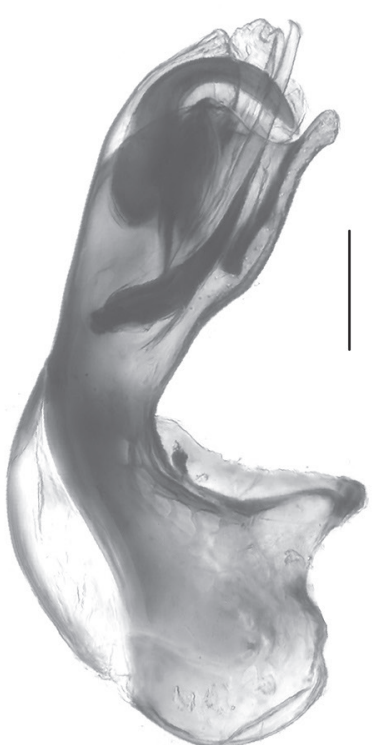

65

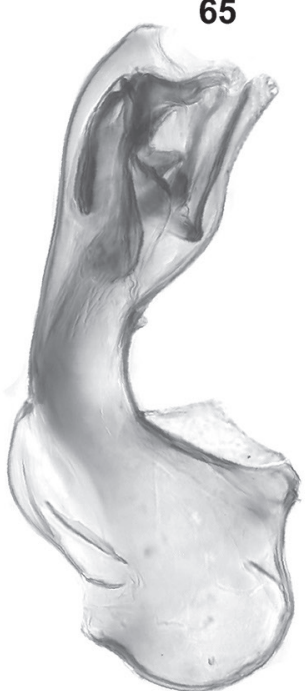

69

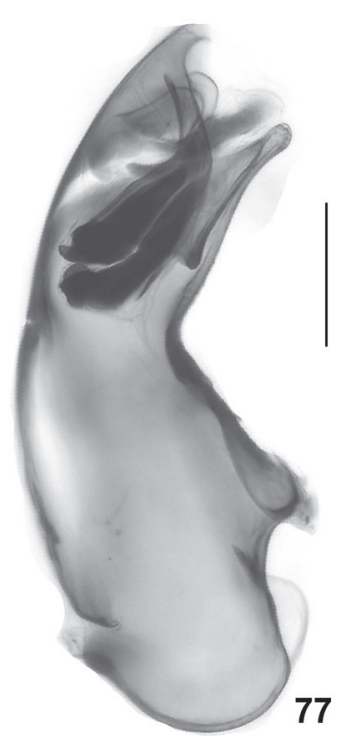

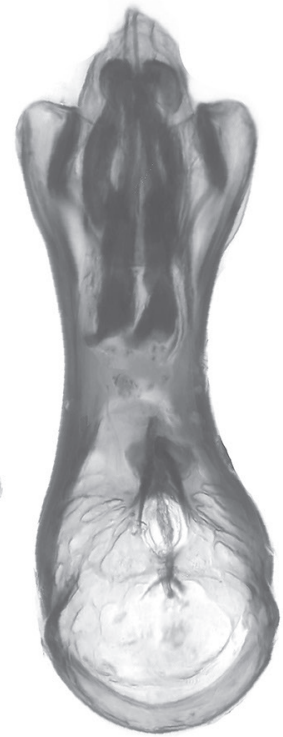

66

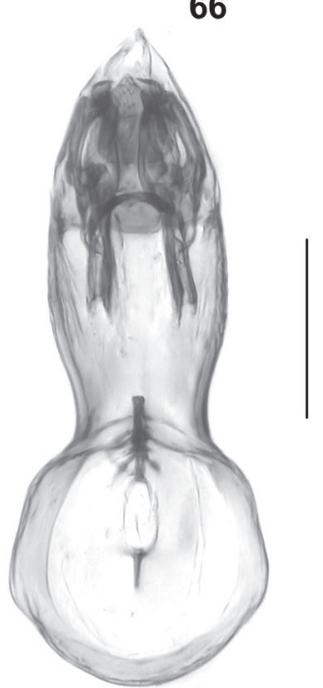

70

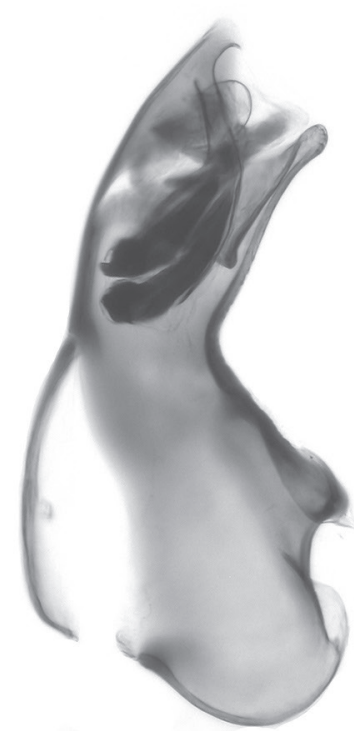

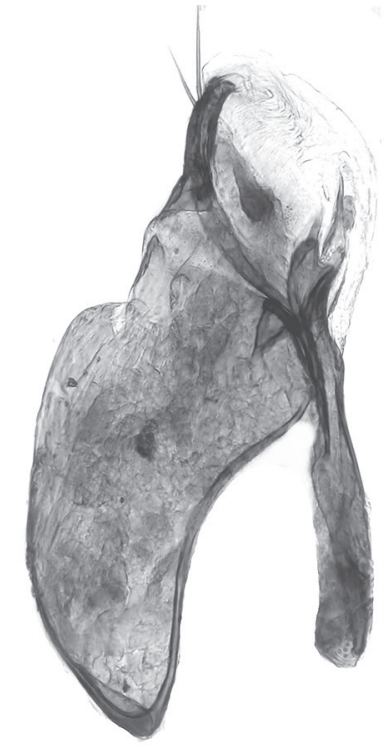

67



71

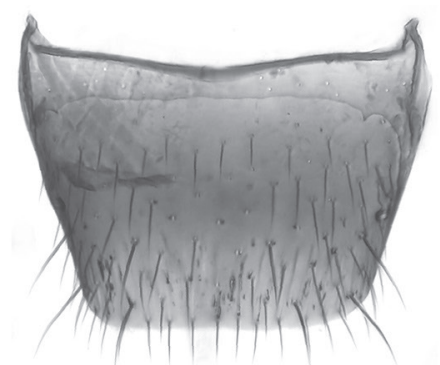

72

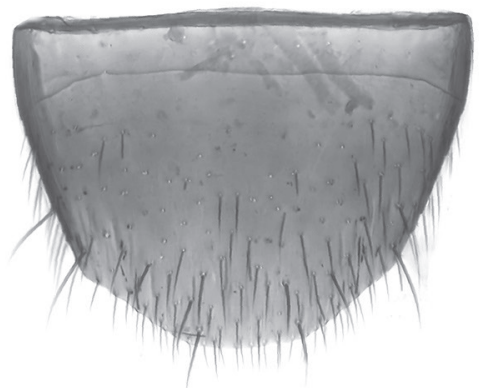

73

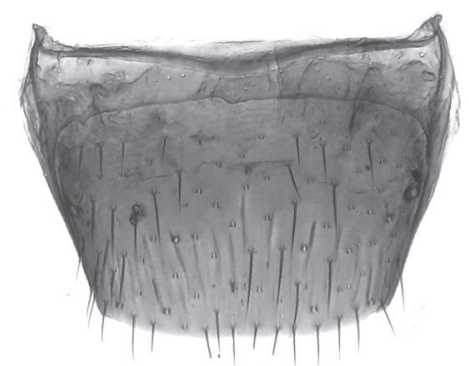

74



75
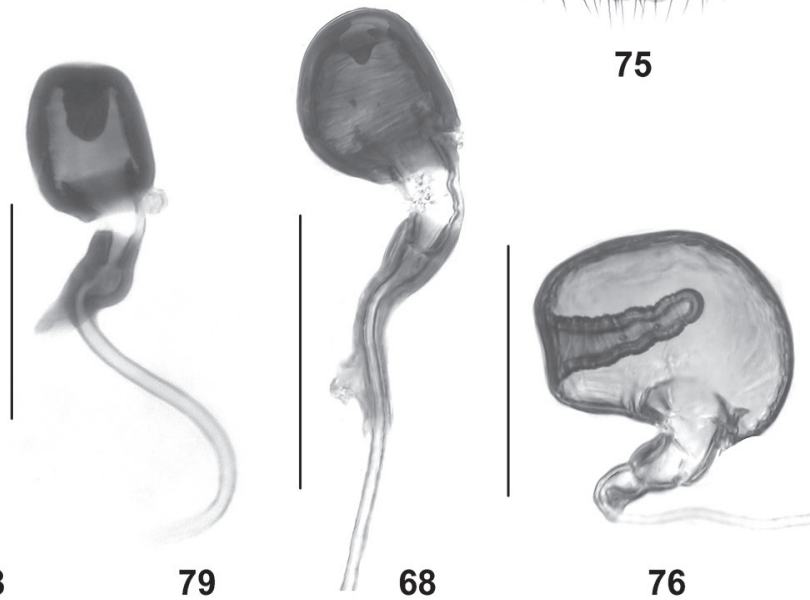

76

Figs 65-79: Leptusa procera (65-68), L. monscangi (69-76), and L. pathibarana (77-79). 65-66, 69-70, 77-78 - median lobe of aedeagus in lateral and in ventral view; 67, 71 - paramere; 72 - male tergite VIII; 73 - male sternite VIII; 74 - female tergite VIII; 75 - female sternite VIII; 68, 76, 79 - spermatheca. Scale bars: 72-75: 0.2 mm; 65-71, 76-79: $0.1 \mathrm{~mm}$. 
$\sigma^{*}$ : posterior margin of tergite VIII distinctly concave to acutely excised (Fig. 21); posterior margin of sternite VII broadly concave, with fringe of very long setae (Fig. 22); posterior margin of sternite VIII angularly pointed in the middle (Fig. 23); median lobe of aedeagus approximately $0.38 \mathrm{~mm}$ long, and shaped as in Figs 19-20; apical lobe of paramere of similar shape as in L. chinensis.

ㅇ: tergite VIII with weakly concave to truncate posterior margin (Fig. 24); posterior margin of sternite VIII convex; spermatheca (Fig. 25) not distinctive.

Comparative notes: Leptusa excisa resembles L. chinensis in habitus and punctation (especially of the pronotum), but differs from this species by a usually distinctly bicoloured forebody, on average smaller body size, shorter and more coarsely punctate elytra, a more strongly concave posterior margin of the male tergite VIII, a less strongly concave posterior margin of the male sternite VII, and particularly by a significantly smaller aedeagus (L. chinensis: median lobe approximately $0.5 \mathrm{~mm}$ long). For illustrations of other Aphaireleptusa species known from mainland China see PACE $(1997,1999,2001,2010)$ and Assing $(2002,2006)$

Distribution and natural history: The specimens were sifted in two close localities in the southern slopes of Qinling Shan, Shaanxi, at altitudes between 1700 and $2600 \mathrm{~m}$.

\section{Leptusa (Aphaireleptusa) grandipennis spec. nov. urn:Isid:zoobank.org:act:476EFE09-A2F0-4227-8F55-AEC9D658E159 (Figs 2, 13, 26-29)}

Type material: Holotype o : "CHINA: N-Sichuan [CH1226], $70 \mathrm{~km} N$ Songpan, road S 301, above Gan lake, $33^{\circ} 15^{\prime} 26^{\prime \prime} \mathrm{N}, 103^{\circ} 46^{\prime} 03^{\prime \prime} \mathrm{E}, 2700 \mathrm{~m}$, spruce forest with birch, litter, mushrooms, moss, and dead wood sifted, 12.VIII.2012, M. Schülke / Holotypus ơ Leptusa grandipennis sp. n. det. V. Assing 2020" (MNB). Paratype ơ: same data as holotype, but leg. Wrase (cAss).

Etymology: The specific epithet (adjective) alludes to the remarkably large elytra (in relation to the head and pronotum).

Description: Body length 3.0-3.1 mm; length of forebody 1.4-1.5 mm. Habitus as in Fig. 2. Colouration: body blackish; legs pale-brown, with the metafemora darker brown and the tarsi yellowish; antennae with antennomeres I-IV reddish-yellow and V-XI dark-brown to blackish-brown.

Head (Fig. 13) weakly transverse; punctation coarse, very dense, and somewhat umbilicate; interstices reduced to narrow ridges, with shallow microsculpture. Eyes large and strongly convex, longer than postocular region in lateral view. Antennae slender, gradually and weakly incrassate apically, preapical antennomeres less than 1.5 times as broad as long.

Pronotum (Fig. 13) 1.2 times as broad as long and 1.2 times as broad as head; maximal width in anterior half; posterior angles angularly marked; punctation coarse, very dense, asperate, and partly rugosely confluent, particularly along middle; interstices without microsculpture.

Elytra (Fig. 13) conspicuously large in relation to head and pronotum, approximately 1.2 times as long and nearly 1.4 times as broad as pronotum; punctation coarse, dense, and defined.

Abdomen much narrower than elytra; punctation distinct and rather dense, very coarse and very dense in anterior impressions of tergites III-V; interstices with very shallow, nearly obsolete microreticulation on tergites III-V and with very distinct microreticulation on tergites VI-VII; posterior margin of tergite VII with distinct palisade fringe.

$\sigma^{*}$ : posterior margin of tergite VIII weakly concave in the middle (Fig. 28); posterior margin of sternite VII truncate, without pronounced fringe of long setae; posterior margin of sternite VIII angularly pointed in the middle (Fig. 29); median lobe of aedeagus small, only $0.33 \mathrm{~mm}$ long, and shaped as in Figs 26-27; apical lobe of paramere of similar shape as in L. chinensis.

o : unknown.

Comparative notes: Among the species of the subgenus Aphaireleptusa, L. grandipennis is most similar to L. chinensis, from which it differs by much more slender antennae, much larger and more prominent eyes, a relatively smaller and more slender head and pronotum, larger and longer elytra (in relation to the pronotum), confluent punctation of the pronotum, and a significantly smaller aedeagus (L. chinensis: median lobe approximately $0.5 \mathrm{~mm}$ long). For illustrations of other Aphaireleptusa species known from mainland China see PACE $(1997,1999,2001,2010)$ and Assing $(2002,2006)$.

Distribution and natural history: The type locality is situated to the north of Songpan, Sichuan. The specimens were sifted from litter in a forest with dominant spruce and interspersed birch at an altitude of $2700 \mathrm{~m}$.

Leptusa (Aphaireleptusa) gonggana spec. nov. urn:Isid:zoobank.org:act:063A3FD3-32D8-4F48-AABA-5AB12CF1A686 (Figs 4, 14, 30, 33-38)

Type material: Holotype $0^{\star}:$ "P.R. CHINA, Sichuan, NE slope Gongga Shan, N29 50'05" E10202'53", 11.vi.2011, 3019 m, sift15, V. Grebennikov / Holotypus o Leptusa gonggana sp. n. det. V. Assing 2020" (CAS). Paratypes: 2 exs.: same data as holotype (CNC, cAss); 1 ex.: "P.R. CHINA, Sichuan, NE slope Gongga Shan, N29 $53^{\circ} 23^{\prime \prime}$ E102 01'31", 8.vi.2011, 3886 m, sift13, V. Grebennikov" (CNC); 1 ex.: "P.R. CHINA, Sichuan, NE slope Gongga 
Shan, N2952'10" E10202'01", 12.vi.2011, $3620 \mathrm{~m}$, sift16, V. Grebennikov" (CNC); 1 ex.: "P.R. CHINA, Sichuan, NE slope Gongga Shan, N2947'49" E10203'46", 14.vi.2011, $2684 \mathrm{~m}$, sift18, V. Grebennikov" (cAss); 1 ex.: "P.R. CHINA, Sichuan, NE slope Gongga Shan, N2950'50" E10202'28", 18.vi.2011, $3170 \mathrm{~m}$, sift21, V. Grebennikov" (cAss).

Etymology: The specific epithet is an adjective derived from the name of the mountain where the species was discovered.

Description: Body length 2.5-2.9 mm; length of forebody $1.2-1.3 \mathrm{~mm}$. Habitus as in Fig. 17. Colouration: body black; legs reddish; antennae blackish-brown with the basal three antennomeres reddish.

Head (Fig. 18) transverse; punctation moderately coarse, dense, moderately umbilicate; interstices narrower than diameter of punctures, with microsculpture. Eyes at least as long as postocular region in lateral view. Antenna slender, gradually and weakly incrassate apically, preapical antennomeres approximately 1.5 times as broad as long. Pronotum (Fig. 18) 1.20-1.25 times as broad as long and approximately 1.25 times as broad as head; maximal width in anterior half; lateral margins sinuate in posterior half; posterior angles angularly marked; punctation dense, moderately coarse, and somewhat asperate, weakly defined; interstices with microreticulation.

Elytra (Fig. 18) approximately 0.9 times as long as pronotum; punctation coarse, rather dense, and defined; interstices with very shallow microreticulation. Hind wings present or reduced to short stubs.

Abdomen slightly broader than elytra; punctation fine and moderately dense, coarse and dense in anterior impressions of tergites III-VI; interstices with microreticulation; posterior margin of tergite VII with palisade fringe; tergite VII without sexual dimorphism.

$\sigma^{\star}$ : tergite VIII (Fig. 19) with weakly concave posterior margin; sternite VII posteriorly broadly and distinctly concave, with long marginal setae; posterior margin of sternite VIII obtusely angled in the middle (Fig. 20); median lobe of aedeagus approximately $0.35 \mathrm{~mm}$ long, shaped as in Figs 21-22; apical lobe of paramere of similar shape as in L. chinensis.

o : tergite VIII (Fig. 23) with truncate posterior margin; posterior margin of sternite VIII broadly, obtusely angled in the middle (Fig. 24); spermatheca (Fig. 16) not distinctive.

Comparative notes: Leptusa gonggana is reliably distinguished from the similar L. gansuensis only by a smaller aedeagus of different shape (L. gansuensis: median lobe of aedeagus approximately $0.45 \mathrm{~mm}$ long). For illustrations of L. gansuensis see PACE (1997).

Distribution and natural history: The specimens were sifted in several close localities in Gongga Shan, West Sichuan, at altitudes of 2680-3890 m.

\section{Leptusa (Aphaireleptusa) habana spec. nov. urn:Isid:zoobank.org:act:217C5415-9901-4E13-8DD8-3F8AEA4CC8C1 \\ (Figs 9, 15, 39-44)}

Type material: Holotype $0^{\star}:$ "CHINA, Yunnan, Haba Shan, N27²1'01", E10005'44", 4072 m, 28.vi.2012, sift35, V. Grebennikov / Holotypus o Leptusa habana sp. n. det. V. Assing 2020" (CAS). Paratypes: 16 exs.: same data as holotype (CNC, cAss); 1 ex.: "CHINA, Yunnan, Haba Shan, N27²0'54", E10004'36", 4222 m, 28.vi.2012, sift35, V. Grebennikov" (CNC); 3 exs.: "CHINA, Yunnan, Haba Shan, N27²0'58", E10005'58", 19.vi.2012, 4114 m, sift24, V. Grebennikov" (CNC); 2 exs.: "CHINA, Yunnan, Haba Shan, N27²1'20", E10006'36", 19.vi.2012, 3826 m, sift25, V. Grebennikov" (CNC); 2 exs.: "CHINA, Yunnan, Haba Shan, N27²1'01", E10005'44", 21.vi.2012, 4072 m, sift26, V. Grebennikov" (CNC, cAss); 2 exs.: "CHINA, Yunnan, Haba Shan, N27²0'47", E10005'33", 27.vi.2012, 4154 m, sift32, V. Grebennikov" (CNC).

Etymology: The specific epithet is an adjective derived from the name of the mountain where the species was discovered.

Description: Body length 2.5-3.3 mm; length of forebody 1.2-1.4 mm. Habitus as in Fig. 9. Colouration: body blackish-brown to black; legs reddish to dark-reddish; antennae brown with the basal three antennomeres reddish.

Head (Fig. 15) transverse; punctation moderately coarse, dense, not umbilicate; interstices narrower than diameter of punctures, with microsculpture. Eyes approximately as long as postocular region in lateral view. Antenna moderately slender, gradually and moderately incrassate apically, preapical antennomeres approximately 1.5 times as broad as long.

Pronotum (Fig. 15) 1.2-1.3 times as broad as long and approximately 1.3 times as broad as head; maximal width in anterior half; posterior angles weakly marked; punctation dense and fine; interstices with distinct microreticulation.

Elytra (Fig. 15) 0.65-0.70 times as long as pronotum; punctation similar to that of head; interstices with microsculpture. Hind wings completely reduced.

Abdomen broader than elytra; tergites III-VI with anterior impressions, that of tergite VI slightly shallower than those of tergites III-V; punctation fine and rather dense; interstices with shallow microreticulation; posterior margin of tergite VII with narrow rudiment of a palisade fringe; tergite VII without sexual dimorphism.

$\sigma^{*}$ : tergite VIII (Fig. 41) with concave to truncate posterior margin; sternite VII posteriorly concave, with long marginal setae; posterior margin of sternite VIII convexly produced in the middle (Fig. 42); median lobe of aedeagus approximately $0.45 \mathrm{~mm}$ long, shaped as in Figs 39-40; apical lobe of paramere of similar shape as in L. chinensis. 
ㅇ: tergite VIII with truncate to weakly convex posterior margin; posterior margin of sternite VIII weakly produced in the middle (Fig. 43); spermatheca (Fig. 44) not distinctive.

Comparative notes: Among the Chinese representatives of the subgenus Aphaireleptusa, L. habana is most similar to L. xuemontis and L. turgida. It differs from them as follows:

- from L.xuemontis by larger eyes, finer punctation of the forebody, and a slightly smaller aedeagus with a much less pronounced median projection of the ventral process (lateral view);

- from L. turgida by longer, darker, and more massive antennae and by a larger aedeagus of slightly different shape (L.turgida: median lobe of aedeagus approximately $0.4 \mathrm{~mm}$ long).

For illustrations of L. xuemontis and L. turgida see PACE (2001) and Assing (2006), respectively.

Distribution and natural history: The specimens were sifted in several close localities in Haba Shan, North Yunnan, at altitudes of 3820-4220 m.

Leptusa (Aphaireleptusa) auriculata spec. nov. urn:Isid:zoobank.org:act:1812AE30-52FF-498D-B8C2-D600DCAB2724 (Figs 3, 16, 45-50, 56-57)

Type material: Holotype $0^{*}$ : "P.R. CHINA, Yunnan, E slope Cangshan at Dali, N2539'54.4", E10005'53.0", 15.v.2010, $3991 \mathrm{~m}$, sifting14, V. Grebennikov / Holotypus o Leptusa auriculata sp. n. det. V. Assing 2020" (CAS). Paratypes: 28 exs.: same data as holotype (CNC, cAss); 15 exs.: "P.R. CHINA, Yunnan, E slope Cangshan at Dali, N2540'24.1", E10005'57.6", 17.v.2010, 3806 m, sifting15, V. Grebennikov" (CNC, cAss); 40 exs.: "P.R. CHINA, Yunnan, E slope Cangshan at Dali, N2540'14.7", E10006.'12.0", 17.v.2010, 3827 m, sifting16, V. Grebennikov" (CNC, cAss); 21 exs.: "P.R. CHINA, Yunnan, E slope Cangshan at Dali, N2540'07.6", E10006'12.9", 18.v.2010, 3887 m, sifting18, V. Grebennikov" (CNC, cAss); 17 exs.: "P.R. CHINA, Yunnan, E slope Cangshan at Dali, N25³9'54.7", E10006'04.5", 19.v.2010, 3815 m, sifting19, V. Grebennikov" (CNC, cAss); 5 exs.: "CHINA, Yunnan, Cang Shan at Dali, N25 40'12", E100'06'10", 3740 m, 05.vii.2011, sift37, V. Grebennikov" (CNC, cAss); 5 exs. [most likely mislabeled]: "CHINA, Sichuan, Emei Shan, N29³2'48.4" E10320'06.3", 2342 m, 17.vi.2010, sifting36, V. Grebennikov" (CNC, cAss).

Etymology: The specific epithet is an adjective derived from the Latin noun auricula (diminutive of auris: ear) and alludes to the shapes of the apical internal structures of the aedeagus.
Description: Body length 2.6-3.2 mm; length of forebody 1.2-1.4 mm. Habitus as in Fig. 3. Colouration: forebody reddish-brown to dark-brown, often with the head at least partly darker; abdomen with segments III-IV reddish-brown to blackish, V-VII blackish, and VIII-X dark-yellow to reddish; legs and antennae reddish.

Head (Fig. 16) transverse; punctation coarse, dense, and umbilicate; interstices narrower than diameter of punctures, with shallow microsculpture. Eyes slightly shorter than postocular region in lateral view. Antennae slender, gradually and moderately incrassate apically, preapical antennomeres approximately 1.5 times as broad as long.

Pronotum (Fig. 16) 1.3-1.4 times as broad as long and approximately 1.3 times as broad as head; maximal width slightly anterior to middle; posterior angles obtusely marked; punctation finer, shallower, and less defined than that of head; interstices with shallow microsculpture.

Elytra (Fig. 16) $0.70-0.75$ times as long as pronotum; punctation dense and much coarser than that of pronotum. Hind wings completely reduced.

Abdomen broader than elytra; punctation distinct and rather dense; interstices with microreticulation; posterior margin of tergite VII with narrow rudiment of a palisade fringe; tergite VII without, tergite VIII with weakly pronounced sexual dimorphism.

$\sigma^{\text {t: }}$ tergite VIII (Fig. 48) with weakly concave posterior margin; sternite VII posteriorly truncate or very weakly concave, with long marginal setae; posterior margin of sternite VIII convexly produced in the middle (Fig. 56); median lobe of aedeagus nearly $0.5 \mathrm{~mm}$ long, shaped as in Figs 45-47; apical lobe of paramere of similar shape as in L. chinensis.

o : tergite VIII (Fig. 49) with weakly concave or truncate posterior margin; posterior margin of sternite VIII broadly and obtusely angled in the middle (Fig. 57); spermatheca (Fig. 50) not distinctive.

Comparative notes: Based on external characters (strongly transverse pronotum, coarsely punctate forebody), long marginal setae at the posterior margin of sternite VIII, and on the morphology of the aedeagus, L. auriculata is assigned to the subgenus Aphaireleptusa. It differs from other representatives of the subgenus recorded from mainland China by the combination of relatively pale colouration of the forebody and a bicoloured abdomen, a coarsely punctate forebody, and by the male sexual characters. For illustrations of other Aphaireleptusa species known from mainland China see PACE $(1997,1999,2001,2010)$ and Assing (2002, 2006).

Distribution and natural history: The specimens were found by sifting litter in several close localities in Cang (Diancang) Shan, Northwest Yunnan, at high altitudes (3740-3990 m). The specimens bearing labels indicating 
Emei Shan as the locality of collection were most likely mislabeled; for additional comments see the section on L. emeiana.

\section{Leptusa (Aphaireleptusa) gonggamontis PACE, 1997}

Material examined: China: Sichuan: 5 exs., Gongga Shan, NE-slope, $29^{\circ} 50^{\prime} \mathrm{N}, 102^{\circ} 03^{\prime} \mathrm{E}, 3020 \mathrm{~m}$, sifted, 11.VI.2011, leg. Grebennikov (CNC, cAss); 4 exs., same data, but $29^{\circ} 51^{\prime} \mathrm{N} ; 102^{\circ} 03^{\prime} \mathrm{E}, 3170 \mathrm{~m}, 9 . \mathrm{VI} .2011$ (CNC, cAss); 1 ex., same data, but $29^{\circ} 48^{\prime} \mathrm{N}, 102^{\circ} 04^{\prime} \mathrm{E}, 2770 \mathrm{~m}$, 6.VI.2011 (CNC); 8 exs., $29^{\circ} 51^{\prime} \mathrm{N}, 102^{\circ} 02^{\prime} \mathrm{E}, 3170 \mathrm{~m}$, 18.VI.2011 (CNC, cAss); 7 exs., same data, but $29^{\circ} 52^{\prime} \mathrm{N}$ $102^{\circ} 02^{\prime} \mathrm{E}, 3620 \mathrm{~m}, 12 . \mathrm{VI} .2011$ (CNC, cAss); 3 exs., same data, but $29^{\circ} 48^{\prime} \mathrm{N} ; 102^{\circ} 04^{\prime} \mathrm{E}, 2680 \mathrm{~m}, 14$.VI.2011 (CNC, cAss); 1 ex., $29^{\circ} 55^{\prime} \mathrm{N}, 102^{\circ} 01^{\prime} \mathrm{E}, 4140 \mathrm{~m}, 13 . \mathrm{VI} .2011$ (cAss); 2 exs., same data, but $29^{\circ} 51^{\prime} \mathrm{N} ; 102^{\circ} 02^{\prime} \mathrm{E}, 3170 \mathrm{~m}$, 21.VI.2011 (CNC, cAss); 3 exs., Ganzi Tibet. Aut. Pref., Luding Co., Erlangshan pass, $7 \mathrm{~km}$ SSE Luding, $29^{\circ} 51^{\prime} \mathrm{N}, 102^{\circ} 15^{\prime} \mathrm{E}, 2600 \mathrm{~m}$, coniferous forest, litter sifted, 29.VI.1999, leg. Schülke (MNB, cAss).

The sole previously known specimens of this species are the holotypes of L. gonggamontis and L. daxuemontis (junior synonym of L. gonggamontis), both collected in the same locality in Gongga Shan. The above material suggests that the species is rather common in this mountain at higher altitudes (2680-4140 m). As can be inferred from the record from Erlang Shan, L. gonggamontis is not endemic to Gongga Shan.

\section{Leptusa (Drepanoleptusa) rougemonti PACE, 1997}

Material examined: China: 11 exs., S-Gansu, N Chengx-


$1750 \mathrm{~m}$, moist valley with stream and ponds, meadow with Artemisia, 28.VII.2012, leg. Assing \& Schülke (cAss, MNB); 1 o $^{\star}$ S-Gansu, N Chengxian, West Qinling Shan, $34^{\circ} 10^{\prime} 20^{\prime \prime} \mathrm{N}, 105^{\circ} 42^{\prime} 19^{\prime \prime} \mathrm{E}, 1830 \mathrm{~m}$, stream valley with secondary deciduous forest, moist litter sifted, 29.VII.2012, leg. Assing (cAss).

Leptusa rougemonti was originally described based on three males from "China, Shanxi, Nonwutai" (PACE 1997). The above specimens represent the first records since the original description and the first records from Gansu.

\section{Leptusa (Drepanoleptusa) pollicita Assing, 2010}

Material examined: China: $10^{\star}$, Yunnan, Lincang Pref., Xue Shan, $11 \mathrm{~km}$ ENE Lincang, $23^{\circ} 55^{\prime} \mathrm{N}, 100^{\circ} 11^{\prime} \mathrm{E}$, $2510 \mathrm{~m}$, secondary pine forest with rhododendron, sifted, 10.IX.2009, leg. Schülke (MNB).
This species was described based on type material collected in Xue Shan and Laobie Shan, North Yunnan.

\section{Leptusa (Drepanoleptusa) jinfomontis PACE, 2001}

This species was originally assigned to the subgenus Nesopisalia PACE, 1992 (PACE 1992). The illustrations provided by PACE (2001) suggest, however, that it is very closely related to L. discolor and L. emeiana (see below) of the subgenus Drepanoleptusa.

Leptusa (Drepanoleptusa) emplenotoides Assing, 2006

Leptusa (Aphaireleptusa) zhongdianensis PACE, 2010: 297; syn. nov.

The original description of L. zhongdianensis is based on a male holotype from "N-Yunnan, Zhongidan Co., $51 \mathrm{~km}$ SSE Zhongdian" and a male paratype from "W-Sichuan Aba Tibetian Aut. Pref. Weizhou Co., Qionglai Shan, Wolong Valley, $69 \mathrm{~km}$ WSW Guanxian" (PACE 2010). As can be inferred from the illustrations of the highly distinctive aedeagus of $L$. zhongdianensis provided by PACE (2010), the type material is undoubtedly conspecific with L.emplenotoides. Hence the synonymy proposed above.

\section{Leptusa (Drepanoleptusa) calliceroides Assing, 2004}

This species, which was previously listed as incertae sedis, is moved to Drepanoleptusa based on the resemblance of the internal structures of the aedeagus to those of L. emplenotoides.

\section{Leptusa (Drepanoleptusa) emeiana spec. nov. urn:Isid:zoobank.org:act:43EA4727-AFD3-4C04-826C-73ADCE6DAEF0 (Figs 5, 51-55)}

Type material: Holotype $0^{\star}:$ "CHINA, Sichuan, Emei Shan, N29³2'48.4", E103²0'06.3", 2342 m, 17.vi.2010, sifting36, V. Grebennikov / Holotypus o Leptusa emeiana sp. n. det. V. Assing 2020" (CAS). Paratypes: 3 exs.: same data as holotype (CNC, cAss); 2 exs.: 'P.R. CHINA, Sichuan, Emei Shan, N2933.6' E103²0.6', 27.vi.-5.vii.2009, 1800-2400 m, siftings11-17 V. Grebennikov" (CNC, cAss); 1 ex.: "P.R. CHINA, Sichuan, Emei Shan, N29³0'46.5", E10319'57.0", 14.vi.2010, 3035 m, sifting28, V. Grebennikov" (CNC); 2 exs.: "P.R. CHINA, Sichuan, Emei Shan, N29³0'54.2", E103¹9'50.6", 14.vi.2010, 3055 m, sifting29, V. Grebennikov" (cAss); 2 exs.: "P.R. CHINA, Sichuan, Emei Shan, N29³2'37.3", E103¹9'57.5", 18.vi.2010, 2440 m, sifting37, V. Grebennikov" (CNC); 1 ex.: "P.R. CHINA, Sichuan, Emei Shan, N29³3'51", E103²0'47", 23.v.2011, 1779 m, sift03, 
V. Grebennikov" (CNC); 2 क $\sigma^{\star}, 1$ ㅇ [most likely mislabeled]: "P.R. CHINA, Yunnan, E slope Cangshan at Dali, N2540'13.2", E10007'54.8", 13.v.2010, 2728 m, sifting08, V. Grebennikov" (CAS, CNC, cAss).

Comment: The description was originally based only on the three specimens bearing labels indicating they were collected in Cang Shan. They were studied nearly ten years ago. Since the species was at that time assumed to be endemic to the Cang (Diancang) Shan, the specific epithet cangica, an adjective derived from the name of the mountain, was chosen, and one of the three specimens was designated as the holotype and labeled accordingly ("Holotypus o Leptusa cangica sp. n. det. V. Assing 2012"). When the material from several localities in Emei Shan was made available only several years later, it appeared very likely that the specimens bearing labels indicating that they were collected in Diancang were in fact mislabeled. Identical confusion was observed for Silusa edentula Assing, in press, and a reverse confusion seems to be true of Leptusa auriculata (see the section on that species).

Etymology: The specific epithet (adjective) is derived from the name of the mountain range where this species was first discovered.

Description: Body length 1.9-2.2 mm. Habitus as in Fig. 5. Colouration: body reddish, with abdominal segment VI and anterior portion of segment VII infuscate; legs and antennae pale-reddish.

Head weakly transverse; punctation dense and shallow; interstices narrower than diameter of punctures, with very shallow microsculpture and glossy; eyes weakly convex and small, little more than half as long as postocular region in lateral view, approximately as large as antennomere I in cross-section. Antennae gradually and moderately incrassate apically, preapical antennomeres approximately twice as wide as long.

Pronotum 1.25-1.30 times as wide as long and 1.201.25 times as wide as head; maximal width in anterior half; posterior angles obtusely marked; punctation finer and less defined than that of head; microsculpture pronounced.

Elytra approximately 0.7 times as long as, and noticeably narrower than pronotum; punctation dense, much coarser than that of pronotum. Hind wings completely reduced.

Abdomen distinctly broader than elytra; punctation fine and not very dense; interstices with shallow microsculpture; posterior margin of tergite VII without palisade fringe.

$\sigma^{*}$ : tergite VII with or without minute median tubercle posteriorly; tergite VIII with truncate and somewhat serrate posterior margin (Fig. 54); sternite VIII (Fig. 55) obtusely angled posteriorly and with fringe of long thin marginal setae; median lobe of aedeagus $0.32-0.33 \mathrm{~mm}$ long, shaped as in Figs 51-52; apical lobe of paramere short, abruptly narrowed apically (Fig. 53).

+ : tergite VIII of similar shape as in male; sternite VIII convex posteriorly; spermatheca not distinctive.

Comparative notes: The median lobe of the aedeagus somewhat resembles that of $L$. discolor, from which the new species is distinguished by numerous characters, particularly its smaller and relatively broader body, shorter antennae, a finer punctation of the forebody, a relatively broader pronotum, a less parallel and broader abdomen with much finer and sparser punctation, and by the different male sexual characters (much shorter and smaller tubercle on the male tergite VII, differently shaped male and female tergites and sternites VIII, different shape of the median lobe of the aedeagus). For illustrations of L. discolor see Assing (2006b).

Distribution and natural history: According to the labels, the type material was sifted in one locality in Diancang (Cang) Shan (Yunnan) and several localities in Emei Shan (Sichuan). This suggests that this small and micropterous species is remarkably widespread, provided that the specimens from Yunnan were not mislabeled; they were collected by V. Grebennikov only a month before some of the paratypes from Emei Shan. Therefore, the presence of this species is Diancang should be considered doubtful for the time being (see also the distribution section of $L$. auriculata above). The altitudes range from 1780 to $3055 \mathrm{~m}$.

\section{Leptusa (Drepanoleptusa) jïzica spec. nov. urn:Isid:zoobank.org:act:D1844B8D-2B3B-4388-933D-F2F98883B6A6 (Figs 6, 17, 58-60)}

Type material: Holotype $0^{\star}$ [teneral]: “CHINA: Yunnan, Dali Bai Aut. Pref., Jizu Shan, summit plateau, $37 \mathrm{~km}$ NE Dali, $25^{\circ} 58^{\prime} 30^{\prime \prime} \mathrm{N}, \quad 100^{\circ} 21^{\prime} 36^{\prime \prime} \mathrm{E}, 3150 \mathrm{~m}$, mixed forest, sifted from litter, moss \& mushrooms, 5.IX.2009, leg. M. Schülke [CH09-28] / Holotypus o Leptusa jizuica sp. n. det. V. Assing 2020” (MNB).

Etymology: The specific epithet is an adjective derived from the name of the mountain where the holotype was collected.

Description: Body length $2.3 \mathrm{~mm}$; length of forebody $1.0 \mathrm{~mm}$. Habitus slender (Fig. 6). Colouration (note that the holotype is slightly teneral]: head blackish-brown; pronotum brown; elytra dark-yellow with the scutellar region diffusely darker; abdomen pale-brown with tergite VI and the anterior portions of tergites V and VII darker; legs yellow; antennae pale-brown with the basal three antennomeres dark-yellow.

Head (Fig. 17) approximately as long as broad; punctation very coarse and dense, interstices reduced to narrow ridges. Eyes longer than postocular region in lateral 
view. Antenna slender; antennomeres IV weakly oblong, $\mathrm{V}-\mathrm{VI}$ approximately as long as broad, VII-X increasing in width and increasingly transverse, and $\mathrm{X}$ barely 1.5 times as broad as long.

Pronotum (Fig. 17) approximately 1.3 times as broad as long and 1.25 times as broad as head; maximal width in anterior half; posterior angles obtusely marked; punctation as coarse and as dense as that of head.

Elytra (Fig. 17) slightly longer than pronotum; punctation as dense as, and even coarser than that of pronotum. Abdomen narrower than elytra; tergites III-V with anterior impressions densely and coarsely punctate; punctation on remainder of tergal surfaces moderately fine and moderately dense; interstices with distinct microsculpture; posterior margin of tergite VII with narrow palisade fringe.

$\mathrm{o}^{\star}$ : tergites VII and VIII unmodified (Fig. 59); posterior margin of sternite VIII obtusely produced in the middle (Fig. 60); median lobe of aedeagus (Fig. 58) approximately $0.25 \mathrm{~mm}$ long, with ventral process and internal structures of distinctive shapes; apical lobe of paramere rather short.

o: unknown.

Comparative notes: This species is readily distinguished from all other congeners recorded from China by the distinctive shapes of the ventral process and the internal structures of the aedeagus and additionally by the combination of small size, slender habitus, and conspicuously coarse punctation of the forebody.

Distribution and natural history: The slightly teneral holotype was found in Jizu Shan, Northwest Yunnan, by sifting litter in a mixed forest at an altitude of $3150 \mathrm{~m}$.

\section{Leptusa (Drepanoleptusa) desculpens spec. nov. urn:Isid:zoobank.org:act:A3342BAF-F31E-43E6-9636-8250A85FBD97 (Figs 7, 18, 61-64)}

Type material: Holotype $\sigma^{*}$ : "CHINA, Yunnan, SE Pingbian, $22^{\circ} 54^{\prime} 31^{\prime \prime} \mathrm{N}, \quad 103^{\circ} 41^{\prime} 44^{\prime \prime E}, 2100 \mathrm{~m}$, primary subtropical broad-leaved forest, litter sifted, 27.VIII.2014, leg. M. Schülke [CH14-22] / Holotypus o Leptusa desculpens sp. n. det. V. Assing 2020" (MNB). Paratype $\sigma^{\top}$ : same data as holotype, but "28.VIII.2014, ... [CH1422a]" (cAss).

Etymology: The specific epithet is the present participle of the Latin verb desculpere (to chisel) and alludes to the chisel-shaped internal structure of the aedeagus.

Description: Body length 2.1-2.4 mm; length of forebody $0.9-1.0 \mathrm{~mm}$. Habitus as in Fig. 7. Colouration: forebody brown to dark-brown with the humeral angles and the posterior margins of the elytra reddish-yellow; legs yellowish; antennae brown with the basal three antennomeres and antennomere XI reddish.
Head (Fig. 18) approximately as long as broad; punctation very coarse and dense, interstices reduced to narrow ridges. Eyes shorter than postocular region in lateral view. Antenna incrassate apically; antennomeres IV weakly transverse, $\mathrm{V}-\mathrm{X}$ increasing in width and increasingly transverse, and $\mathrm{X}$ approximately twice as broad as long.

Pronotum (Fig. 18) approximately 1.2 times as broad as long and 1.2 times as broad as head; maximal width in anterior half; posterior angles marked; punctation similar to that of head, but somewhat less coarse.

Elytra (Fig. 18) approximately 0.8 times as long as pronotum, extensively impressed; punctation very coarse, dense and asperate. Hind wings reduced.

Abdomen approximately as broad as elytra; tergites III-V with anterior impressions densely and coarsely punctate; punctation distinct and moderately fine, dense on anterior tergites and sparser on posterior tergites; interstices glossy, without distinct microsculpture; posterior margin of tergite VII without palisade fringe; tergites VII and VIII sexually dimorphic.

$\sigma^{\star}$ : tergites VII and VIII each with oblong postero-median tubercle (Fig. 63); posterior margin of sternite VIII obtusely produced in the middle (Fig. 64); median lobe of aedeagus approximately $0.3 \mathrm{~mm}$ long, shaped as in Figs 61-62; internal structures of distinctive shapes; apical lobe of paramere distinctly oblong.

o: unknown.

Comparative notes: This species is readily distinguished from all other congeners recorded from China by the distinctive internal structures of the aedeagus and additionally by the combination of small size, slender habitus, and conspicuously coarse punctation of the forebody.

Distribution and natural history: Leptusa desculpens is currently the sole representative of the genus known from Southeast Yunnan. The specimens were sifted from litter in a primary broad-leaved forest in Dawei Shan, Yunnan, at an altitude of $2100 \mathrm{~m}$.

\section{Leptusa (Chondre/ytropisalia) procera spec. nov. urn:Isid:zoobank.org:act:C3881039-6537-452F-974C-48BDAFD02762 Figs 8, 65-68)}

Type material. Holotype $\sigma^{*}$ : "CHINA [26] - N-Sichuan

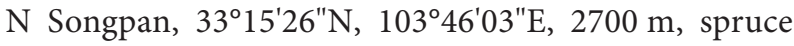
forest with birch, 12.VIII.2012, V. Assing / Holotypus ○ Leptusa procera sp. n. det. V. Assing 2020" (cAss). Paratypes: $2 \sigma^{\star} \sigma^{\star}, 8$ 우 $[1$ 울 with additional label "Laboulbeniales n. 3767, Walter Rossi"]: same data as holotype (cAss); 12 exs.: "CHINA: N-Sichuan [CH1226.], $70 \mathrm{~km}$ N Songpan, road S 301, above Gan lake, $33^{\circ} 15^{\prime} 26^{\prime \prime} \mathrm{N}, 103^{\circ} 46^{\prime} 03^{\prime \prime} \mathrm{E}, 2700 \mathrm{~m}$, spruce forest with birch, litter, mushrooms, moss, and dead wood sifted, 12.VIII.2012, M. Schülke" (MNB, cAss); 1 ex., same data, leg. Wrase (MNB). 
Etymology: The specific epithet (Latin, adjective: slim, slender) alludes to the conspicuously slender habitus of this species.

Description: Body length 3.4-4.3 mm; length of forebody $1.5-1.9 \mathrm{~mm}$. Habitus (Fig. 8) very slender. Colouration: body reddish to reddish-brown with the head darkbrown to blackish-brown and with most of tergite VI and the anterior portion of tergite VII blackish; legs and antennae reddish.

Head approximately as long as broad or weakly oblong; punctation moderately coarse and dense; interstices without microsculpture. Eyes small, composed of approximately 30 ommatidia, less than half as long as postocular region in dorsal view. Antenna $1.1-1.3 \mathrm{~mm}$ long, weakly incrassate apically; antennomere IV weakly oblong; antennomere X slightly more than 1.5 times as broad as long.

Pronotum weakly transverse, $1.15-1.20$ times as broad as long and 1.15-1.20 times as broad as head, broadest anteriorly and strongly tapering posteriad, strongly convex in cross-section; lateral margins weakly sinuate near posterior angles in dorsal view; punctation denser than that of head and somewhat granulose; interstices without microsculpture.

Elytra approximately 0.9 times as long as pronotum; punctation very coarse and distinctly granulose, much coarser than that of head and pronotum; interstices without microsculpture. Hind wings completely reduced.

Abdomen significantly broader than elytra, broadest at segment VI, without microsculpture; tergites III-VI with pronounced, deep anterior impressions; anterior impressions of tergites III-V in the middle with distinct, densely and coarsely punctate elevation, laterally nearly smooth; discs of tergites III-V with distinct and weakly granulose punctation; anterior impression of tergite VI with very coarse punctures; disc of tergite VI and all of tergites VIIVIII with moderately sparse and very fine punctation; posterior margin of tergite VII with narrow rudiment of a palisade fringe.

$\sigma^{\top}$ : tergite VII without keel; tergite VIII without keel or tubercle, posterior margin weakly concave in the middle; posterior margin of sternite VIII convex, with long thin marginal setae; median lobe of aedeagus approximately $0.55 \mathrm{~mm}$ long, shaped as in Figs 65-66, with pair of pronounced claw-shaped apical internal structures; paramere slightly longer than median lobe and shaped as in Fig. 67.

$9:$ posterior margin of tergite VIII of similar shape as in male or with truncate posterior margin; sternite VIII with convex posterior margin; spermatheca small, shaped as in Fig. 68.

Comparative notes: Leptusa procera is readily distinguished from L. tectusoides, the only other representative of the subgenus Chondrelytropisalia known from Sichuan, by numerous external characters alone: significantly larger body size (L. tectusoides: body length $3.1 \mathrm{~mm}$; length of forebody $1.2 \mathrm{~mm}$ ), much longer and more massive antennae (L.tectusoides: length of antennae $0.8 \mathrm{~mm}$ ), much more coarsely and granulosely punctate and longer elytra, the medially elevated and differently punctate anterior impressions of the abdominal tergites III-V. Aside from these differences, $L$. procera is distinguished from $L$. tectusoides by a much larger aedeagus with internal structures of completely different shapes. For illustrations of L. tectusoides see Assing (2002).

Distribution and natural history: The type locality is situated to the north of Songpan in North Sichuan, China. The specimens were sifted in a spruce forest with interspersed birch at an altitude of $2700 \mathrm{~m}$. Two of the paratypes were infested with Monoicomyces sp., Laboulbeniales (det. W. Rossi).

\section{Leptusa (Heteroleptusa) flagellata Assing, 2002}

Material examined. China: 1 , Shaanxi, Qinling Shan, pass on road Zhouzhi-Foping, $105 \mathrm{~km}$ SW Xian, $33^{\circ} 44^{\prime} \mathrm{N}, 107^{\circ} 59^{\prime \prime} \mathrm{E}, 1990 \mathrm{~m}$, small stream valley with mixed deciduous forest and bamboo undergrowth, sifted, 2-4.VII.2001, leg. Schülke (MNB); 1 옹 Shaanxi, Qinling Shan, $52 \mathrm{~km}$ SSW Zhouzhi, $33^{\circ} 44^{\prime} \mathrm{N}, 107^{\circ} 58^{\prime} \mathrm{E}, 1990 \mathrm{~m}$, stream valley with mixed forest, 25.VII.2012, leg. Schülke (cAss).

The above females were collected at or near the type locality.

\section{Leptusa (Yunnaleptusa) recta Assing, 2006}

Material examined: China: 2 exs., Yunnan, Nujiang Lisu Aut. Pref., Gaoligong Shan, valley 18 km W Gongshan, $27^{\circ} 48^{\prime} \mathrm{N}$; $98^{\circ} 30^{\prime} \mathrm{E}, 3020 \mathrm{~m}$, mixed forest, litter sifted, 7.VI.2007, leg. Schülke (MNB, cAss).

The original description is based on a unique male collected close to the locality where the above specimens were found.

\section{Leptusa (Yunnaleptusa) armatissima Assing, 2008}

Material examined: China: $1 \sigma^{\star}$, Diancang Shan, W Dali, $25^{\circ} 42^{\prime} \mathrm{N}, 100^{\circ} 06^{\prime} \mathrm{E}, 2960 \mathrm{~m}$, litter sifted, 6.IX.2009, leg. Schülke (MNB).

The known distribution of this species is confined to Diancang Shan, Northwest Yunnan. 
Leptusa (Yunnaleptusa) monscangi spec. nov. urn:Isid:zoobank.org:act:2B2ECDE0-93FD-42BB-BF27-6D7C7B8E38BC (Figs 19, 69-76)

Type material. Holotype $0^{\star}$ : "P.R. CHINA, Yunnan, E slope Cangshan at Dali, N2540'24.1", E10005'57.6", 17.v.2010, 3806 m, sifting15, V. Grebennikov / Holotypus o Leptusa monscangi sp. n. det. V. Assing 2020" (CNC). Paratypes: 12 exs.: same data as holotype (CNC, cAss); 4 exs.: "P.R. CHINA, Yunnan, E slope Cangshan at Dali, N25³9'54.4", E10005'53.0", 15.v.2010, 3991 m, sifting14, V. Grebennikov" (CNC, cAss); 7 exs.: "P.R. CHINA, Yunnan, E slope Cangshan at Dali, N2540'01.9", E10005'45.5", 15.v.2010, 4063 m, sifting13, V. Grebennikov" (CNC, cAss); 7 exs.: "P.R. CHINA, Yunnan, E slope Cangshan at Dali, N2540'14.7", E10006.'12.0", 17.v.2010, $3827 \mathrm{~m}$, sifting16, V. Grebennikov" (CNC, cAss); 4 exs.: "P.R. CHINA, Yunnan, E slope Cangshan at Dali, N2540'07.6", E10006'12.9", 18.v.2010, $3887 \mathrm{~m}$, sifting18, V. Grebennikov" (CNC, cAss); 11 exs.: "P.R. CHINA, Yunnan, E slope Cangshan at Dali, N2539'54.7", E10006'04.5", 19.v.2010, 3815 m, sifting19, V. Grebennikov" (CNC, cAss); 2 exs.: exs.: "CHINA, Yunnan, Cang Shan at Dali, N2540'12", E100 06'10", 3740 m, 05.vii.2011, sift37, V. Grebennikov" (CNC, cAss).

Etymology: The specific epithet is a noun composed of the Latin noun mons (mountain) and the genitive of the name of the mountain where this species may be endemic.

Description: Body length 1.6-2.2 mm; length of forebody $0.8-1.0 \mathrm{~mm}$. Habitus as in Fig. 19. Colouration: head reddish to blackish-brown; pronotum and elytra reddish; abdomen with segments III-IV reddish to blackish, V-VII blackish, and VIII-X reddish; legs and antennae reddish.

Head transverse; punctation fine and rather sparse; interstices with shallow microsculpture. Eyes slightly more than half as long as postocular region in lateral view. Antennae moderately slender, gradually and moderately incrassate apically, preapical antennomeres approximately 1.5 times as broad as long.

Pronotum approximately 1.3 times as broad as long and approximately 1.3 times as broad as head; maximal width slightly anterior to middle; posterior angles weakly marked, nearly obsolete; punctation fine and rather dense; microsculpture more distinct than that of head.

Elytra approximately 0.75 times as long as pronotum; punctation dense, more distinct than that of head and pronotum. Hind wings completely reduced.

Abdomen broader than elytra; punctation very fine and moderately dense; interstices with shallow microsculpture; posterior margin of tergite VII with narrow rudiment of a palisade fringe; tergites VII and VIII without pronounced sexual dimorphism; posterior margin of tergite VIII with weakly concave to weakly convex posterior margin (Figs 72, 74). $o^{*}$ : posterior margin of sternite VIII convex (Fig. 73); median lobe of aedeagus approximately $0.35 \mathrm{~mm}$ long, shaped as in Figs 69-70; apical lobe of paramere moderately long and moderately slender (Fig. 71).

ㅇ: posterior margin of sternite VIII convex (Fig. 75); spermatheca (Fig. 76) with long and slender apical invagination and with short proximal portion.

Comparative notes: As can be inferred from the similar external and sexual characters (structure of median lobe of aedeagus and paramere; shape of spermatheca; shapes of male and female sternite VIII; habitus and colouration), this species is undoubtedly very closely allied to L. recta and L.curvata, both of them endemic to individual mountains in North Yunnan. It is reliably distinguished from them only by the structure of the median lobe of the aedeagus. For illustrations of L. curvata and L. recta see Assing (2006).

Distribution and natural history: The specimens were found by sifting litter in several close localities in Cang (Diancang) Shan, Northwest Yunnan, at high altitudes $(3740-4060 \mathrm{~m})$, in nearly all localities together with L. auriculata.

\section{Caucasus region \\ Leptusa (Leptusa) pulchella (MANnERHEIM, 1830)}

Material examined: Russia: 3 exs., Krasnodarskiy Kray, Mezmay env., Temnolesskaya, 750 m, 12.VI.1999, leg. Smetana (CNC, cAss); 2 ex., same data, but 850 m, 8-9. VI.1999 (CNC, cAss); 2 exs., Adygeia, 14 km NE Mt. Fisht, Lagonaki Plateau, 1700 m, 16.VI.1999, leg. Smetana (CNC, cAss).

This species is widespread and common in nearly all of the West Palaearctic region. In the Caucasus region, it had been reported only from Georgia and Armenia (Assing 2017). The above specimens represent the first records from the Russian South European territory.

\section{Leptusa (Neopisalia) venusta (HосннUтн, 1849)}

Material examined: Russia: 2 exs., Krasnodarskiy Kray, Adler, Chvizhepse env., 433' $32^{\prime \prime} \mathrm{N}, 40^{\circ} 04^{\prime} 45^{\prime \prime} \mathrm{E}, 300 \mathrm{~m}$, beech forest, 4.VII.2014, leg. Kovalev (cKov); 13 exs., Krasnodarskiy Kray, Mezmay env., Temnolesskaya, 750 m, 12.VI.1999, leg. Smetana (CNC, cAss); 2 exs., same data, but 7.VI.1999 (CNC, cAss); 2 exs., same data, but 850 m, 9.VI.1999 (CNC, cAss); 2 exs., Krasnodarskiy Kray, Mezmay env., Guama, 950-1000 m, 11.VI.1999, leg. Smetana (CNC, cAss); 3 exs., Adygeia, 14 km NE Mt. Fisht, Lagonaki Plateau, 1700 m, 16.VI.1999, leg. Smetana (CNC, cAss); 1 ex., same data, but 14.VI.1999 
(CNC); 3 exs., Adygeia, 12 km NE Mt. Fisht, Lagonaki Plateau, 1800 m, 14.VI.1999, leg. Smetana (CNC).

Leptusa venusta is the most common of the Caucasian species of the genus. Its distribution is mapped in Assing (2017).

\section{Leptusa (Neopisalia) gibbera Assing, 2011}

Material examined: Russia: 2 exs., Krasnodarskiy Kray, Mezmay env., Temnolesskaya, 750 m, 12.VI.1999, leg. Smetana (CNC, cAss); 1 ex., same data, but but 850 m, 9.VI.1999 (CNC); 1 ex., Krasnodarskiy Kray, Mezmay, 800m, 18.VI.1999, leg. Smetana (CNC); 1 ex., Adygeia, 14 km NE Mt. Fisht, Lagonaki Plateau, 1700 m, 16.VI.1999, leg. Smetana (cAss); 4 exs., Adygeia, 12 km NE Mt. Fisht, Lagonaki Plateau, 1800 m, 14.VI.1999, leg. Smetana (CNC, cAss).

The above material represents the first records since the original description, which is based on five type specimens from the environs of Temnolesskaya in the Krasnodar region.

\section{Leptusa (Neopisalia) microphthalma ReITTER, 1887}

Material examined: Russia: 1 ex., Krasnodarskiy Kray,


beech forest, 4.VII.2014, leg. Kovalev (cAss); 1 ex., same data, but 10.VII.2014 (cKov); 2 exs., Krasnodarskiy Kray, Adler, Kazachiy Brod env., 4331'39"N, 3959'05"E, 270 m, Buxus litter, 19.VII.2014, leg. Kovalev (cKov, cAss); 2 exs., Krasnodarskiy Kray, Mezmay, 800 m, 18.VI.1999, leg. Smetana (CNC, cAss); 2 exs., Krasnodarskiy Kray, Mezmay env., Temnolesskaya, 850 m, 19.VI.1999, leg. Smetana (CNC); 1 ex., same data, but 750 m, 12.VI.1999 (cAss); 73 exs., Krasnodarskiy Kray, Mezmay env., Guama, 950-1000 m, 11.VI.1999, leg. Smetana (CNC, cAss); 6 exs., same data, but $1000 \mathrm{~m}, 10 . \mathrm{VI} .1999$ (CNC, cAss); 2 exs., Krasnodarskiy Kray, Lazarevsky district, Soloniki env., 300 m, 6.VI.2017, leg. Gontarenko (cGon); 1 ex., same data, but 550 m, 4.VI.2017 (cGon); 4 exs., same data, but $400 \mathrm{~m}, 10 . \mathrm{VI} .2017$ (cGon, cAss); 1 ex., Krasnodarskiy Kray, Tuapse district, Olginka env., Saray Gora, 400 m, 20.V.2017, leg. Gontarenko (cGon); 1 ex., Krasnodarskiy Kray, Tuapse district, Olginka env., Agria, 60 m, 29.V.2017, leg. Gontarenko (cAss); 6 exs., Krasnodarskiy Kray, Tuapse district, Krivenkovskoe env., 600 m, 26.V.2017, leg. Gontarenko (cGon, cAss).

Leptusa microphthalma is not uncommon in the West Caucasus; for a distribution map see Assing (2017).

\section{Leptusa (Neopisalia) abchasica Bernhauen, 1936}

Material examined: Russia: 7 exs., Krasnodarskiy Kray, Adler, Kazachiy Brod env., 4331'39"N, 3959'05"E, 270 m, Buxus litter, 19.VII.2014, leg. Kovalev (cKov, cAss).

This species was previously known only from the type locality in Abkhazia. The above specimens represent the first record from Russia.

\section{Leptusa (Neopisalia) svanetica Assing, 2017}

Material examined: Georgia: 8 exs., Kvemo Svaneti, NE-slope of Egrisskiy mountain range, between Lakhashuri and Lamanashuri rivers, $42^{\circ} 44^{\prime} \mathrm{N}, 42^{\circ} 44^{\prime} \mathrm{E}$, 1250 m, 23.IV.2016, leg. Khachikov (cKov, cAss); 2 exs., Zemo Svaneti, Egrisskiy mountain range, NE-slopes of Otepura-Dudi mountain, left bank of Tkheishi river, Kvemo-Vedi env., 425' $\mathrm{N}, 42^{\circ} 12^{\prime} \mathrm{E}, 910 \mathrm{~m}, 15 . \mathrm{IV} .2016$, leg. Khachikov (cAss).

The above material represents the first records since the original description, which is based on three specimens from a locality in Kvemo Svaneti.

\section{Leptusa (Roubaliusa) storkani RouBAL, 1917}

Material examined: Georgia: 7 exs., Kvemo Svaneti, NE-slope of Egrisskiy mountain range, between Lakhashuri and Lamanashuri rivers, $42^{\circ} 44^{\prime} \mathrm{N}, 42^{\circ} 44^{\prime} \mathrm{E}$, 1250 m, 23.IV.2016, leg. Khachikov (cKov, cAss). Russia: 55 exs., Adygeia, 14 km NE Mt. Fisht, Lagonaki Plateau, 1700 m, 16.VI.1999, leg. Smetana (cAss, CNC); 6 exs., Adygeia, $12 \mathrm{~km}$ NE Mt. Fisht, Lagonaki Plateau, $1800 \mathrm{~m}$, 14.VI.1999, leg. Smetana (cAss, CNC); 4 exs., Krasnodarskiy Kray, Temnolesskaya near Mezmai [= Mezmay], 750 m, 12.VI.1999, leg. Smetana (CNC); 1 ex., same data, but 800 m, 8.VI.1999 (CNC); 1 ex., Krasnodarskiy Kray, Mezmay, 800 m, 18.VI.1999, leg. Smetana (CNC); 2 exs., Krasnodarskiy Kray, Mezmay env., Guama, 950-1000 m, 11.VI.1999, leg. Smetana (CNC).

Leptusa storkani is common in the western Greater Caucasus; its distribution is mapped in Assing (2017).

\section{Leptusa (Stictopisalia) caucasica EpPeLSHeIm, 1878}

Material examined: Georgia: 8 exs., Kvemo Svaneti, NE-slope of Egrisskiy mountain range, between Lakhashuri and Lamanashuri rivers, $42^{\circ} 44^{\prime} \mathrm{N}, 42^{\circ} 44^{\prime} \mathrm{E}$, 1250 m, 23.IV.2016, leg. Khachikov (cKov, cAss).

Leptusa caucasica is distributed in parts of both the Greater and the Lesser Caucasus; its distribution is mapped in Assing (2019). 


\section{Leptusa (Dysleptusa) fuliginosa (AuBÉ, 1850)}

Material examined. Russia: 1 ㅇ, Krasnodarskiy Kray, Adler, Kazachiy Brod env., 4331'39"N, 3959'05"E, 270 m, Buxus litter, 19.VII.2014, leg. Kovalev (cAss); 1 , Krasnodarskiy Kray, Mezmay env., Temnolesskaya, 800 m, 8.VI.1999, leg. Smetana (CNC).

This species is one of the most widespread Caucasian species (Assing 2019). For a distribution map see Assing (2017).

\section{Himalayan region}

Leptusa (Chondrelytropisalia) pathibarana spec. nov. urn:Isid:zoobank.org:act:ED968EFF-8133-4318-992C-A4D401C04ADB (Figs 11, 31-32, 77-79)

Type material: Holotype o*: "E-NEPAL, D: Taplejung, W-slope Pathibara 3000-3400 m, 14./16.V.2016, $27^{\circ} 26^{\prime} 20^{\prime \prime} \mathrm{N}, 8^{\circ} 46^{\prime} 44^{\prime \prime}$ E, leg. J. Schmidt / Holotypus o Leptusa pathibarana sp. n. det. V. Assing 2017” (NME). Paratypes: 2 exs.: same data as holotype (NME); 6 exs.: same data, but "E-slope" [probably erroneous, since the coordinates are identical to those of the holotype] (NME, cAss).

Etymology: The specific epithet is an adjective derived from the name of the mountain where the type locality is situated.

Description: Body length 3.1-3.5 mm; length of forebody 1.4-1.5 mm. Habitus as in Fig. 11. Colouration: forebody reddish-brown to dark-brown; abdomen reddish-brown to blackish-brown, with the posterior margins of the tergites and the abdominal apex reddish to yellowish red; legs brown to dark-brown; antennae brown with antennomeres I-III and XI reddish.

Head (Fig. 31) approximately as long as broad; punctation coarse and dense; interstices narrower than diameter of punctures, with or without very shallow microsculpture visible only at high magnification. Eyes small, composed of approximately 30-40 ommatidia, approximately half as long as postocular region in dorsal view. Antenna 0.9-1.0 mm long, weakly incrassate apically; antennomere IV oblong; antennomere $\mathrm{X}$ approximately 1.5 times as broad as long.

Pronotum (Fig. 31) weakly transverse, approximately 1.1 times as broad as long and 1.20-1.25 times as broad as head, strongly convex in cross-section; lateral margins sinuate near posterior angles in dorsal view; punctation distinct and dense, somewhat less coarse than that of head; interstices without microsculpture; pubescence long, pale, and sub-erect to erect.

Elytra (Fig. 31) 0.85-0.90 times as long as pronotum; punctation very coarse, much coarser than that of head; interstices without microsculpture. Hind wings completely reduced.

Abdomen (Fig. 32) approximately as broad as elytra; tergites III-VI with pronounced, deep anterior impressions; punctation rather sparse and fine; interstices without microsculpture and very glossy; posterior margin of tergite VII with narrow rudiment of a palisade fringe; tergites VII and VIII with sexual dimorphism.

$\sigma^{*}$ : tergite VII with marked, long and narrow median keel extending along at least the posterior half of tergite (Fig. 32); tergite VIII with weakly pronounced median keel in posterior portion, posterior margin distinctly concave in the middle and somewhat serrate (due to insertions of marginal setae); posterior margin of sternite VII indistinctly concave and with conspicuously long and dark marginal setae; posterior margin of sternite VIII obtusely pointed in the middle; median lobe of aedeagus approximately $0.42 \mathrm{~mm}$ long, shaped as in Figs 77-78; paramere slightly longer than median lobe, with short and broad apical lobe.

$q$ : posterior margin of tergite VIII weakly concave in the middle; sternite VIII with convex posterior margin; spermatheca small, shaped as in Fig. 79.

Comparative notes: The subgenus Chondrelytropisalia is currently represented by ten species and seven subspecies distributed in the Himalaya from Central Nepal to Sikkim and West Bengal, and in China (Yunnan, Sichuan, and Shaanxi provinces). Leptusa pathibarana is reliably distinguished from all of them by the shape of the median lobe of the aedeagus in lateral view. For illustrations of the sexual characters of other species recorded from East Nepal see PACE (1989) and Assing (2011a).

Distribution and natural history: The type locality is situated in Mount Pathibara in the extreme northeast of Nepal, very close to the border with the Indian province Sikkim. The type specimens were collected at an altitude between 3000 and $3400 \mathrm{~m}$.

\section{Other regions}

\section{Leptusa (Dysleptusa) honshuica Assing, 2002}

Material examined: Japan: $1 \sigma^{*}$, Hokkaido, Ebetsu city, Nopporo Virgin Forest, sifted, 5.V.2006, leg. Lackner (cAss).

This species was originally described based on a single male from a locality in Honshu (Assing 2002). The above specimen represents the first record from Hokkaido. 


\section{Leptusa (Aphaireleptusa) puthzi Assing, 2002}

Material examined: Japan: 3 exs., Honshu, Yamanashi Pref., pass Kitazawatoge, Ashiyasu-mura, 28.VII.-4. VIII.2001, leg. Ueno (MNB, cAss).

The original description is based on type specimens from Tochigi, Shizuoga, and Yamanashi prefectures. The above material was collected in the same locality as two paratypes.

\section{Leptusa (Eospisalia) lackneri Assing, 2011}

Material examined: South Korea: 7 exs., Jeollanam-do,

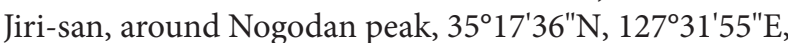
$1500 \mathrm{~m}$, rocky slope of tourist trail with bushes, soilwashing $20 \mathrm{~cm}$ deep at rock base under tree, 15.IX.2010, leg. Makranczy \& al.; 4 exs., same data, but "from grass roots, debris at stones, tufts, flotation; 3 exs.: same data, but "from grass roots and leaf litter at stones, sifting (24C)"; 2 exs., Gangwon-do, Seorak-san, 2 km W Misiryeong pass, rest station, $38^{\circ} 13^{\prime} 04^{\prime \prime} \mathrm{N}, 128^{\circ} 25^{\prime} 12^{\prime \prime} \mathrm{E}$, forest with Acer, near stream, $600 \mathrm{~m}$, soil-washing $25 \mathrm{~cm}$ deep at rocks, 10.IX.2010, leg. Makranczy \& al. (material in HNHM, NIBR, cAss).

The above material is highly similar to the type material from Tsushima island (Assing 2011b), but differs by a more robust body (no overlap), a distinctly bicoloured abdomen, coarser and more defined punctation of the forebody, a more distinctly punctate abdomen, relatively longer elytra, and a slightly larger aedeagus. However, the shape and internal structures of the aedeagus are practically identical, so that the populations from South Korea are tentatively hypothesized to be conspecific with that of Tsushima Island.

\section{Acknowledgements}

I am indebted to the colleagues listed in the material section, in particular Michael Schülke and Aleš Smetana, for the loan of material. Benedikt Feldmann (Münster) and Michael Schülke proof-read and reviewed the manuscript. Their helpful suggestions are much appreciated.

\section{References}

Assing, V. 2002: New species and records of Leptusa KraAtz from the Palaearctic region (Coleoptera: Staphylinidae, Aleocharinae). - Linzer Biologische Beiträge 34 (2): 971-1019.
Assing, V. 2004: Two new species, two new synonyms, and new records of Leptusa Kraatz (Coleoptera: Staphylinidae, Aleocharinae). - Linzer Biologische Beiträge 36 (2): 643-653.

Assing, V. 2006: Six new species and additional records of Leptusa from northern Yunnan, China (Coleoptera: Staphylinidae, Aleocharinae). - Linzer Biologische Beiträge 38 (2): 1157-1174.

Assing, V. 2008: Seven new species and additional records of Palaearctic Leptusa, primarily from Yunnan, China (Coleoptera: Staphylinidae, Aleocharinae). - Linzer Biologische Beiträge 40 (1): 251-273.

Assing, V. 2010: Three new species of Leptusa from Yunnan, with a catalogue of the Leptusa species recorded from China and Taiwan (Coleoptera: Staphylinidae: Aleocharinae). - Linzer Biologische Beiträge 42 (2): 1155-1167.

Assing, V. 2011a: New species and additional records of Leptusa from the Caucasus region and the Himalaya (Coleoptera: Staphylinidae: Aleocharinae). - Linzer Biologische Beiträge 43 (1): 253-265.

Assing, V. 2011b: The first species of Leptusa from Tsushima, Japan (Coleoptera: Staphylinidae: Aleocharinae). - Linzer Biologische Beiträge 43 (1): 267-270.

Assing, V. 2017: On the Leptusa fauna of the Caucasus region (Coleoptera: Staphylinidae: Aleocharinae). Linzer Biologische Beiträge 49 (2): 1049-1074.

Assing, V. 2019: On the Leptusa fauna of the Caucasus region II. A new species and additional records from Georgia, and three new synonymies (Coleoptera: Staphylinidae: Aleocharinae). - Acta Musei Moraviae, Scientiae Biologicae 104 (1): 35-44.

PACE, R. 1989: Monografia del genere Leptusa KraAtz (Coleoptera Staphylinidae). - Memorie del Museo Civico di Storia Naturale di Verona (II ${ }^{\circ}$ Serie), Sezione Scienze della Vita (A: Biologica) 8: 1-307.

PACE, R. 1992: Il genere Leptusa KraATz della sottoregione indocinese (Taiwan e Vietnam). Monografia del genere Leptusa Kraatz: Supplemento I (Coleoptera: Staphylinidae). - Elytron 5 [1991]: 111-119.

PAce, R. 1995: Nuove specie di Leptusa KR. di Taiwan. Monografia del genere Leptusa KraAtz: Supplemento V (Coleoptera Staphylinidae). Bollettino della Società Entomologica Italiana, Genova 126: 243-248.

Pace, R. 1996: Nuove specie di Leptusa KraAtz di Taiwan. Monografia del genere Leptusa Kraatz: Supplemento VI (Coleoptera Staphylinidae). Bollettino della Società Entomologica Italiana, Genova 128: 29-36.

PACE, R. 1997: Specie del genere Leptusa in Cina. Monografia del genere Leptusa Kraatz: Supplemento VII (Coleoptera, Staphylinidae). Revue Suisse de Zoologie 104 (4): 751-760. 
Pace, R. 1999: Nuove Leptusa della Cina. Monografia del genere Leptusa KraATZ: Supplemento X (Coleoptera, Staphylinidae). - Beiträge zur Entomologie, Berlin 49 (2): 369-376.

PACE, R. 2001: Nuove specie cinesi del genere Leptusa. Monografia del genere Leptusa KRAATZ: Supplemento XII (Coleoptera, Staphylinidae). - Bollettino del Museo Regionale di Scienze Naturali, Torino 18: 151-160.

PACE, R. 2004: Specie nuove o poco note di Homalotini, Silusini, Bolitocharini, Diestotini e Autaliini della Cina e della Thailandia (Coleoptera, Staphylinidae). - Revue Suisse de Zoologie 111: 63-76.

Pace, R. 2007: Nuovi dati e nuove specie del genere Leptusa Kraftz di Taiwan. Monografia del genere Leptusa Kr. Supplemento XIV (Coleoptera, Staphylinidae). - Bollettino del Museo Civico di Storia Naturale di Verona 31: 141-145.
PACE, R. 2010: Biodiversità delle Leptusa della Cina, monografia del genere Leptusa KraAtz. Supplemento XVI (Coleoptera, Staphylinidae, Aleocharinae). - Beiträge zur Entomologie, Keltern 60 (2): 295-299.

Schülke, M. \& Smetana, A. 2015: Staphylinidae, pp. 304-1134. - In: LöвL, I. \& LöвL, D. (eds), Catalogue of Palaearctic Coleoptera. New, updated Edition. Volume 2. Hydrophiloidea - Staphylinoidea. Revised and updated edition. - Leiden: Brill: xxvi + 1702 pp. 